Historic, Archive Document

Do not assume content reflects current scientific knowledge, policies, or practices. 



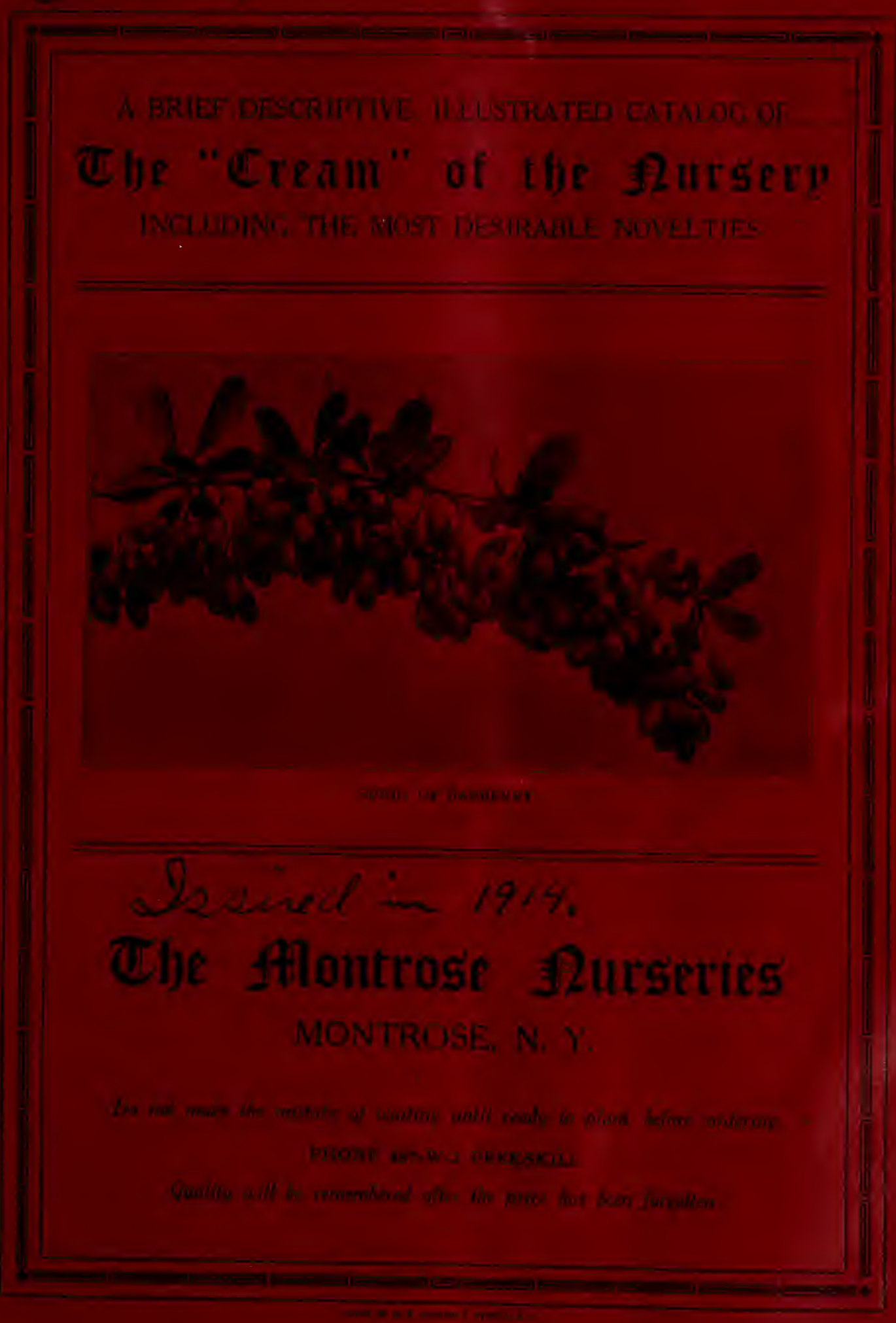




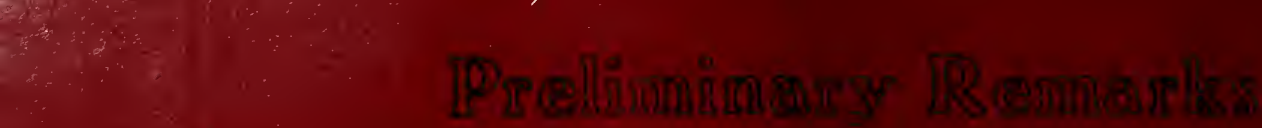

过

wö

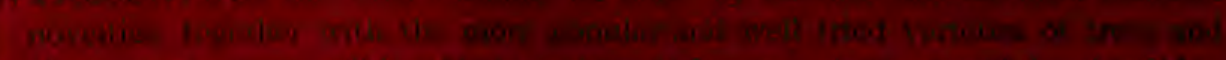

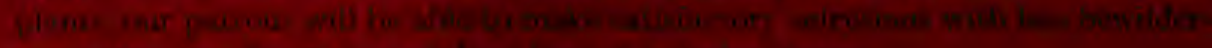

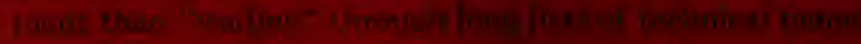

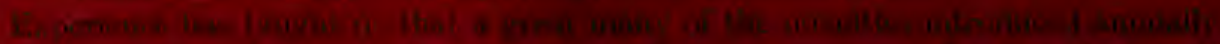

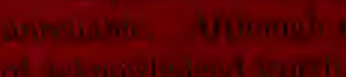

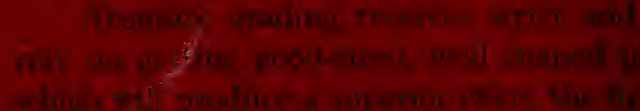

18.

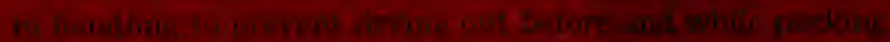

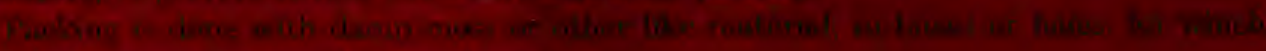

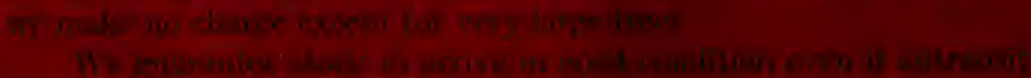

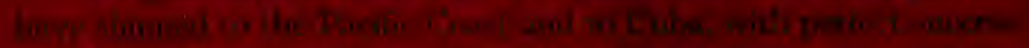

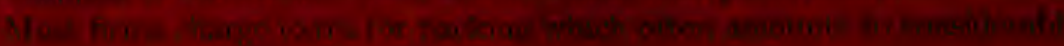

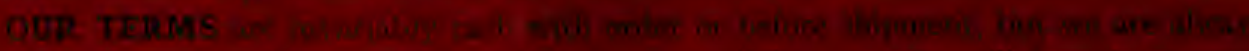

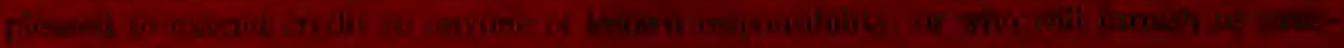

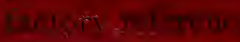

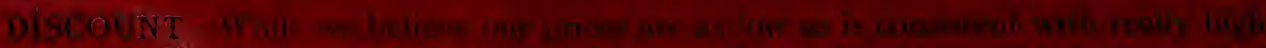
x.at

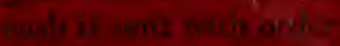

I.

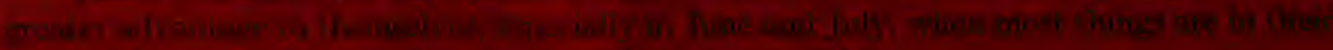

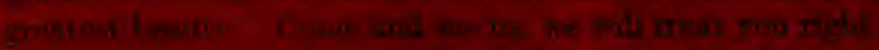

4. Wh

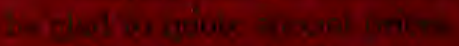

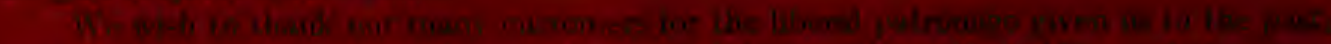

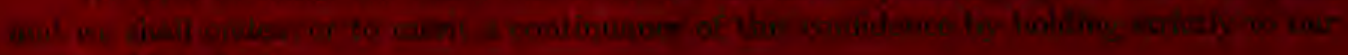

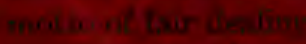

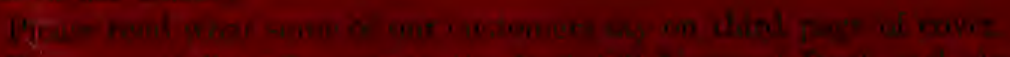

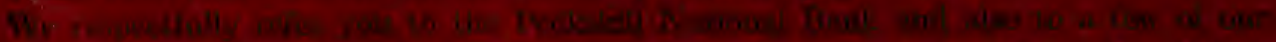

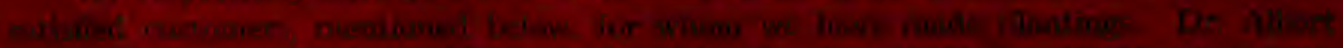
C.

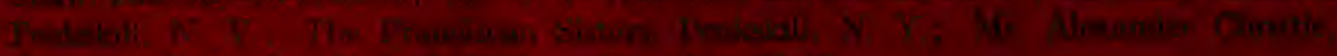

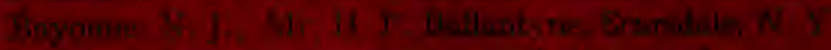

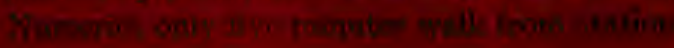

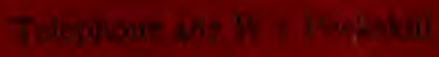

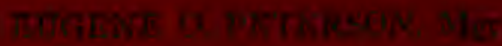

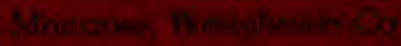




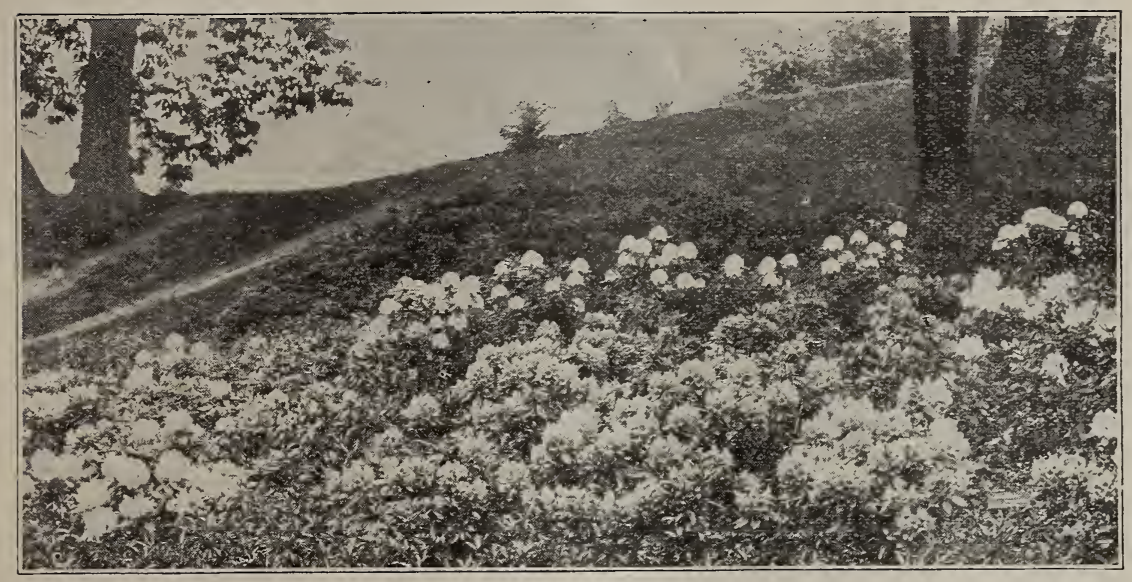

A BED OF RHODODENDRONS

See page II for prices
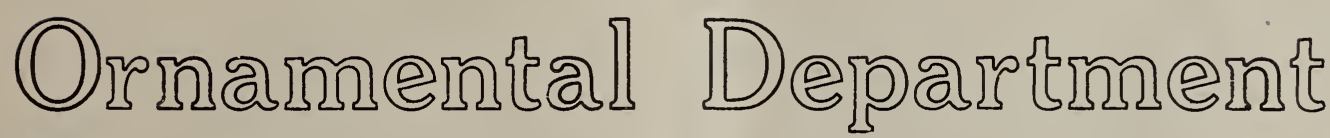

7 EOPLE are beginning to realize that by expending a little time and thought they can have wellkept, attractive grounds at moderate expense adding to the beauty and value of same.

If the grounds are somewhat extensive, beautiful effects can be produced with shade trees, shrubs, etc., according to some prearranged plan.

If grounds are small, a few shrubs, roses, vines and herbaceous plants can be used to advantage.

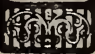
Vines trained over porches, fences, etc., are very effective at small cost.

We would emphasize the fact that you should buy only the best. It is not quantity but quality that counts. We have a fine stock of all kinds of shade trees, shrubs, etc.

\section{HOW TO PLANT}

Do not make the mistake of planting at random all over the grounds. Trees and shrubs may be planted along the drive leading to the house as well as on the borders.

In laying out the grounds, make as few walks as possible. Upright shrubs, roses, and flowers should be planted in clumps.

These beds should be kept well cultivated, to insure healthy growth. Mass the shrubs and most of the trees on the boundaries, so as to leave a broad space for the lawn, and where there is a pretty view leave an opening. Where there is an unsightly object, conceal it with trees or vines or both.

Do not plant large trees too near the house except on the sunny side for shade.

\section{BIRCH (Betula)}

American White Birch. Somewhat irregular growth, very ornamental, with its striking white bark. $6-8 \mathrm{ft} ., \$ 1.00$.

European White Birch. More erect and symmetrical than the above. 8 to $10 \mathrm{ft}$., $\$ 1.25$.

\section{BEECH (Fagus)}

The Beeches should be severely pruned when planted.

Copper Beech. Beautiful copper colored foliage. 3 to 4 ft., $\$ 1.25$.

Rivers' Purple Beech. 4 to $5 \mathrm{ft}$., $\$ 1.50$.

\section{CATALPA BUNGEI}

A remarkable dwarf species, usually grafted on stems 6 to $7 \mathrm{ft}$. high, when it forms a dense round head-see illustration. They are very desirable for formal planting where something is desired that will never get very tall, as at either side of an entrance drive, or path, or in some cases, even on the lawn.

Plants we offer have extra strong heads. Two to three years old, $\$ 2.00$ to $\$ 4.00$ each.

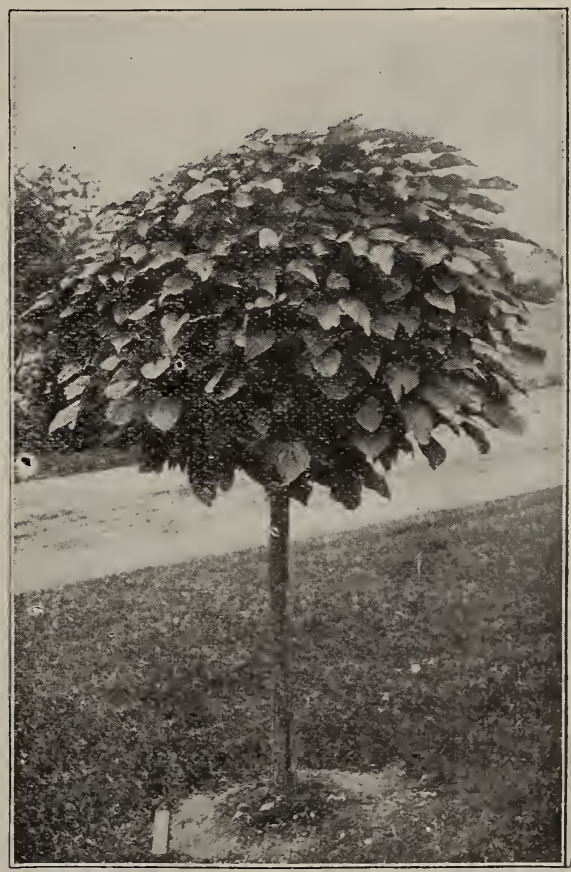




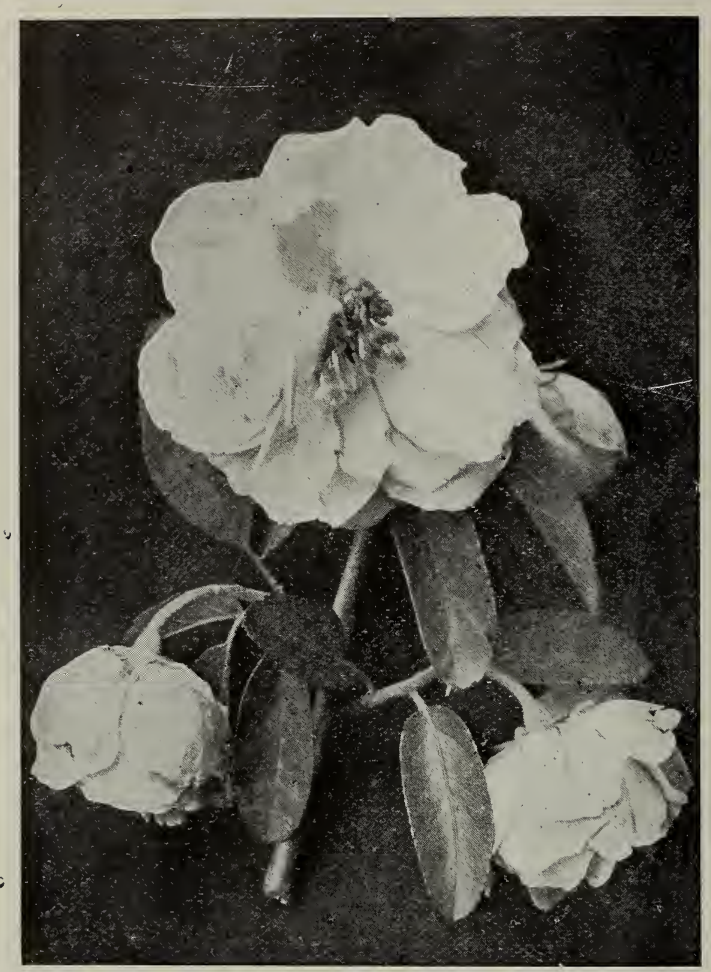

Bechtel's Flowering Crab

\section{THE DOGWOODS (Cornus)}

Are among the most beautiful and desirable medium sized trees; indeed, we know of no other tree that has so much to recommend it.

In early spring before the leaves show, it is covered with large, pure white flowers, followed by bunches of brilliant scarlet berries, and in autumn the foliage coloring is unsurpassed.

Beautiful as a specimen lawn tree, among shrubs bery groups or as a screen.

It does well in shaded positions as well as in the open.

Selected plants, 4 to $5 \mathrm{ft}$., at $\$ 2.00$ to $\$ 3.00$ each. 5 to $7 \mathrm{ft}$., $\$ 2.50$ to $\$ 4.00$ each.

Cornus Flore Rubra. Red or PINk Flowering DoGwOoD. This is identical with the above, except the flowers are a beautiful pink. Very attractive. A rare tree. Fine stocky plants, about $4 \mathrm{ft}$., $\$ 2.25$.

\section{CRAB (Pyrus)}

Bechtel's Double Flowering. A most welcome addition to our list of flowering trees. The flowers are very double, 2 to 3 inches across, of a delicate pink color, resembling a rose, both in form and fragrance. 4 to $5 \mathrm{ft}$., $\$ 1.25$ each. See cut above.

Parkmanii, Parkman's Crab. A beautiful sort 'with drooping, rosy pink flowers. 3 to $4 \mathrm{ft}$., $\$ 1.00$.

\section{LINDEN OR BASSWOOD (TILIA)}

Of the Lindens the European species is perhaps the most largely planted, of this we offer two varieties. The large leaved, which makes an upright, symmetrical tree of large size, seems to be the more popular of the two, probably on account of its more rapid growth, and that it almost always grows very straight. The foliage is dark green and very dense. See cut. 8 to $10 \mathrm{ft}$., $\$ 2.00,10$ to $12 \mathrm{ft}$., $\$ 2.50$ to $\$ 4.00$.

The small leaved sort, sometimes called English Linden, makes a symmetrical tree in time. It is usually somewhat irregular in growth of stem, but with care it can be made to grow fairly straight; the foliage is small but very thick and the branches are set very thick or what is called "twiggy." Much slower growth than the former. Good thrifty trees, 7 to $8 \mathrm{ft}$., $\$ 1.50$.

The American Species. Tillia Americana, has the same general characteristics, except the foliage is a lighter green and larger. The most rapid growing of the Lindens. Selected trees, 8 to $10 \mathrm{ft}$., $\$ 1.00 ; 10$ to $12 \mathrm{ft}$., $\$ 2.00$ to $\$ 4.00$ each.

White Leaved Linden. Tillia Americana Argentea. Is a beautiful and very desirable variety of the American species, the foliage is a light silvery or greyish green, the bark also is very light. Fine trees, 7 to $8 \mathrm{ft}$., $\$ 1.50 ; 10$ to $12 \mathrm{ft}$., $\$ 2.50$.

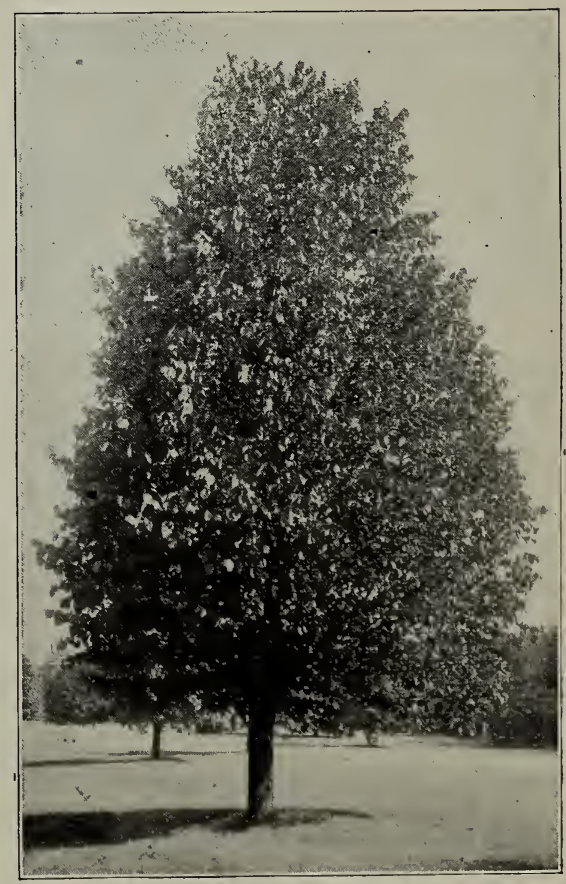

EUROPEAN LINDEN 
Acer Platanoides Schwedlerii. A curious and very beautiful variety of the well known Norway Maple. It is of strong, sturdy growth, making a large spreading tree when given room. The foliage is especially attractive in spring and early summer, being a rich reddish purple gradually changing to dark green. Fine young trees, 8 to $9 \mathrm{ft}$., $\$ 1.50$ each.

Scarlet Maple. Acer Rubrum. A particularly desirable sort, generally found in low, damp ground, though it thrives on almost any upland soil. In early spring it is covered with racemes of small scarlet flowers, and in the autumn the foliage is indescribably beautiful with its many tints of scarlet, orange, golden, purple, etc. It makes a large, well formed tree.

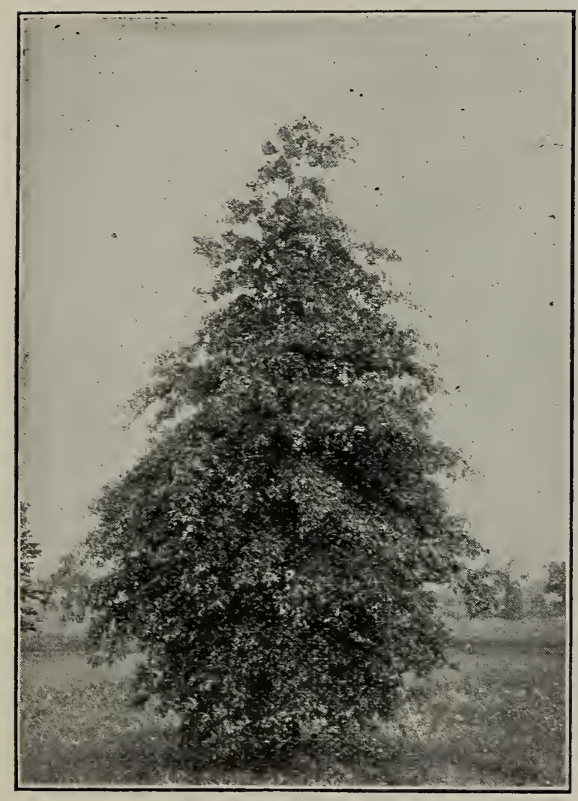

PrN OAK
We offer some fine specimens, 8 to $10 \mathrm{ft}$., $\$ 1.25$ each; 10 to $12 \mathrm{ft}$., $\$ 2.00$ each.

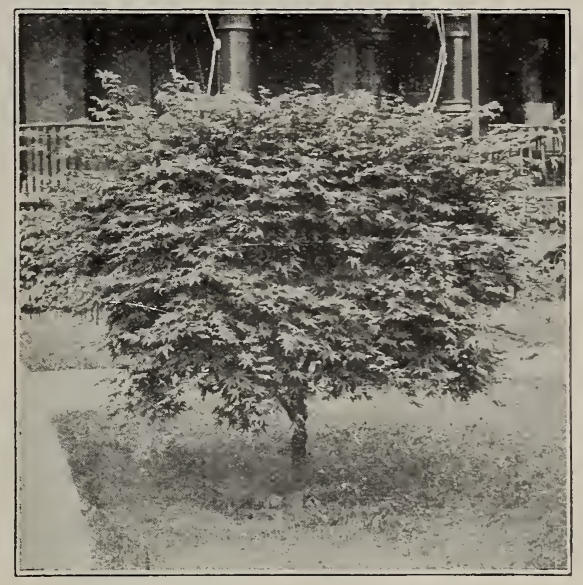

JAPANESE MAPLE (Polymorphum)

\section{JAPAN MAPLES} ACER JAPONICA

We call special attention to this beautiful class of Maples.

They are the daintiest and most exquisite small trees with beautiful colored and variegated foliage. There is nothing so charming in hardy trees as this beautiful class of plants. They are perfectly hardy and will grow anywhere in our northernistates.

The following varieties are the cream of the list:

Acer Polymorphum Atropurpureum. BLOOD-LEAF JAPAN MAPLE. Rich, blood-red foliage holding its color nearly all summer. Fine stocky plants, 2 to $21 / 2 \mathrm{ft}$., at $\$ 2.00$ each.

A. Polymorphum Dissectum. A charming variety with deeply cut fernlike leaves; reddish purple in color, graceful, somewhat drooping form. $1 \frac{1}{2}$ to 2 ft., $\$ 2.00$ each.

A. Polymorphum Lacilifolium. Lace-leaved. Another beautiful sort, distinct from all the others, quite spreading; it takes on magnificent autumn tints. $2 \mathrm{ft}$., $\$ 1.50$ to $\$ 2.00$ each.

A. Polymorphum Aureum. Beautiful golden foliage. 2 ft., $\$ 2.50$.

\section{OAK (Quercus)}

We wish to call particular attention to the Oaks on account of their hardiness, sturdiness and their adaptability to any soil or situation, besides their beauty as a shade or ornamental lawn or street tree.

Of all the varieties, we believe (all points considered) the Pin Oak, Quercus PALustris, is the best and most satisfactory and is the most largely planted. It is the most rapid growing of the species.

The tree is of good form and seems to be immune from disease or injury from insects. The foliage is deep green, quite deeply cut or notched, turning to scarlet and purple in fall. Fine selected trees, 7 to $8 \mathrm{ft}$., $\$ 1.50$ each; extra fine specimens, 8 to $10 \mathrm{ft}$., $\$ 2.00$ to $\$ 3.00$ each.

White Oak. Quercus AlbA. Very large size at maturity; foliage remains on the tree very late in fall. 7 to $8 \mathrm{ft}$., $\$ 1.50$.

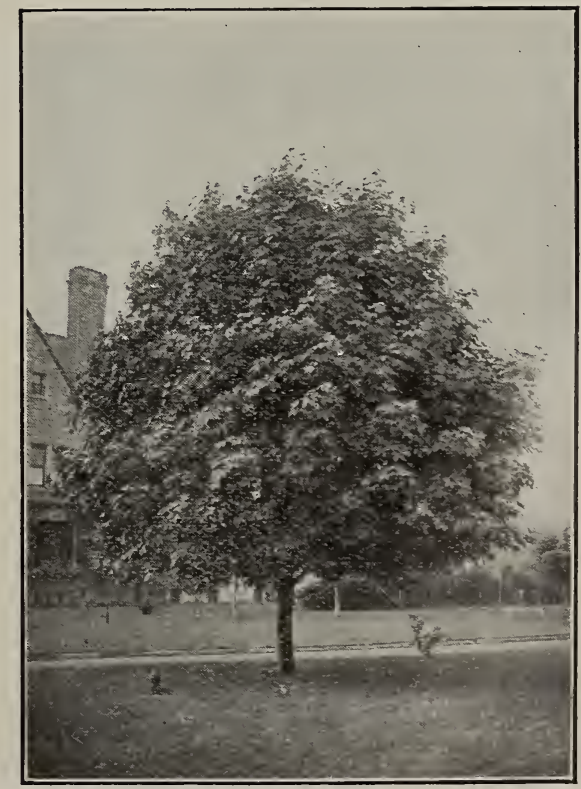

Schwedler's Norway Maple 


\section{GENERAL LIST OF SHADE AND ORNAMENTAL TREES}

\section{CATALPA SPECIOSA}

The large growing sort, 8 to $10 \mathrm{ft}$., $\$ 1.00$ each.

\section{ELM (Ulmus)}

American. 10 to $12 \mathrm{ft}$., $\$ 1.25$ each.

\section{HORSE CHESTNUT (Aesculus)}

White-Flowering. 8 to $10 \mathrm{ft}$., $\$ 1.50$ each. Red-Flowering. 5 to $6 \mathrm{ft}$., $\$ 1.75$.

\section{JUDAS TREE OR RED BUD (Cercis)}

American. 5 to $6 \mathrm{ft}$., $\$ 1.00$ each.

Japan. $21 / 2$ to $3 \mathrm{ft}$., $75 \mathrm{c}$.

\section{LIQUID AMBAR}

Sweet Gum. 6 to $8 \mathrm{ft}$., $\$ 1.00$.

\section{MAPLE (Acer)}

Var. Dasycarpum. Silver or Soft Maple. Most rapid growing of the Maples. 8 to $10 \mathrm{ft}$., $50 \mathrm{c}$ each, $\$ 5.00$ doz.; $1 \mathrm{r} / 2$ to 2 inch caliper, $\$ 1.00$ each, $\$ 10.00$ doz.; 2 to 3 inch caliper, $\$ 2.00$ to $\$ 4.00$ each. Larger sizes priced on application.

, Platanoides. Norway Maple. $10 \mathrm{ft}$. and up. $\$ 1.25$ each, $\$ 12.00$ per doz.; $11 / 2$ to 2 inch caliper, $\$ 2.00$ to $\$ 3.00$ each, $\$ 20.00$ to $\$ 30.00$ per doz.

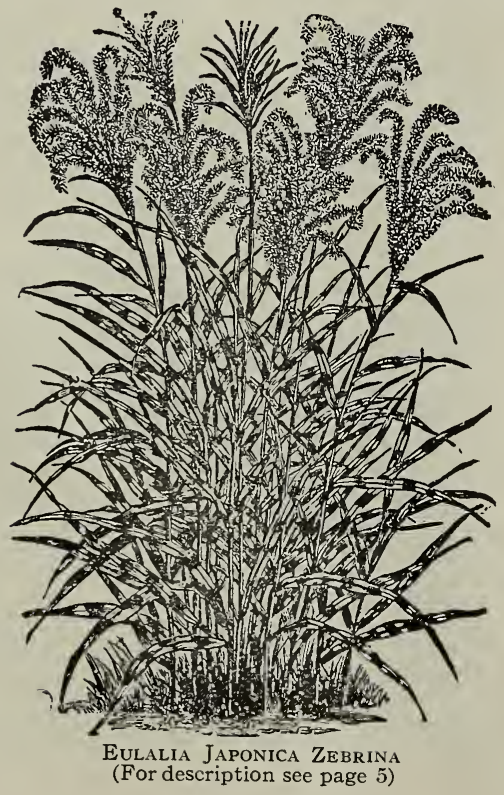

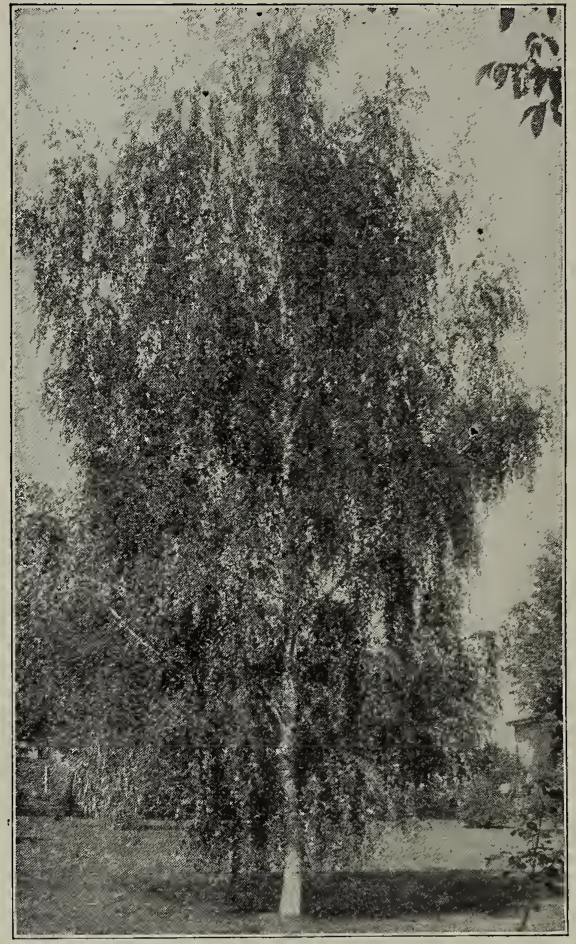

WeEping Cut-Leaf Birch

Saccharium. SugAR or Rock MAPLE. 10 to $12 \mathrm{ft}$., $\$ 1.50$ each, $\$ 15.00$ per doz.; $11 / 2$ to 2 inch caliper, $\$ 2.00$ to $\$ 2.50$ each.

Wieri. Wier's Cut-Leaf MaPle. A very desirable cut-leaved variety of the Silver Maple. 10 to $12 \mathrm{ft}$., $\$ 2.00$.

\section{POPLAR (Populus)}

Carolina. The most rapid growing, hardy tree. 12 to $14 \mathrm{ft}$., $75 \mathrm{c}$ to $\$ 1.00$ each, $\$ 10.00$ per doz.

Lombardy. 8 to $10 \mathrm{ft}$., $60 \mathrm{c}$ each, $\$ 5.00$ per doz.; 10 to $12 \mathrm{ft}$., $\$ 1.00$ each, $\$ 9.00$ per doz. Larger sizes priced on application.

\section{SYCAMORE}

Plane Tree. Will grow almost anywhere, even near the sea-shore. 10 to $12 \mathrm{ft}$., $\$ 1.25$ each.

\section{SALISBURIA}

Maiden-Hair or Ginko. A tall tree from the South, but perfectly hardy. 8 to $10 \mathrm{ft}$., $75 \mathrm{c}$ each. 


\section{WEEPING TREES}

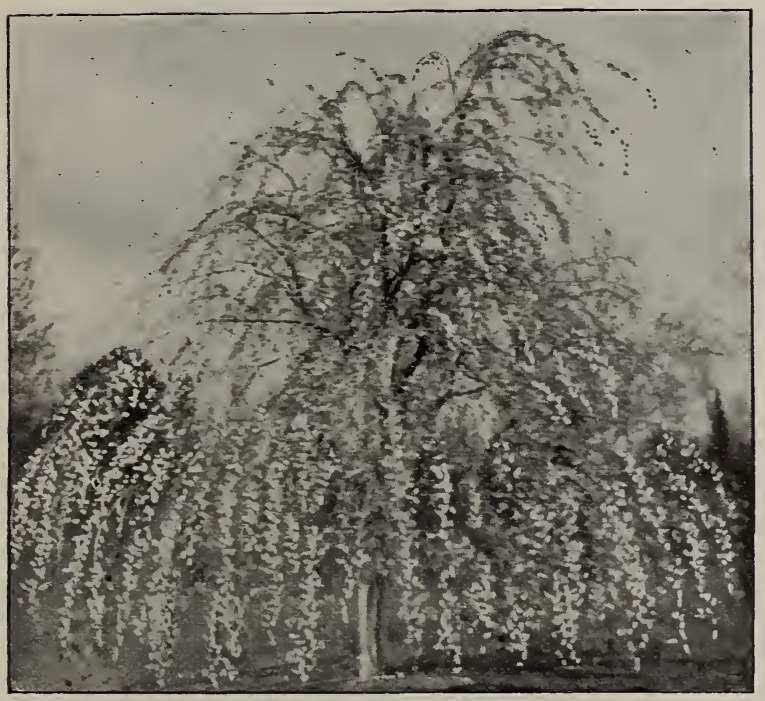

\section{CHERRY}

Japan Weeping. One of the most charming of the Weeping trees, especially when covered with its rose-colored flowers in early May. 5 to $6 \mathrm{ft}$., \$1.50. See cut opposite.

\section{ELM (Ulmus)}

Camperdown Weeping. Extra strong heads. $\$ 2.50$. See cut.

\section{MULBERRY}

Teas' Weeping. Forms a perfect umbrella shaped head, long, slender branches drooping to the ground. Extra strong, 3 and $4 \mathrm{yr}$. heads, $\$ 1.50$ to $\$ 3.00$ each. See cut.

\section{WILLOW}

Babylonian Weeping. The most popular of the Willows. 8 to $10 \mathrm{ft}$., $75 \mathrm{c}$.

Wisconsin Weeping. Another fine drooping form. 8 to $10 \mathrm{ft}$., $75 \mathrm{c}$ to $\$ 1.50$.

JAPAN WEEPING ChERRY

\section{BIRCH}

Cut-leaf Weeping. $8 \mathrm{ft} ., \$ 1.25$. See cut page 4.

B. Young's Weeping. $\$ 1.50$.

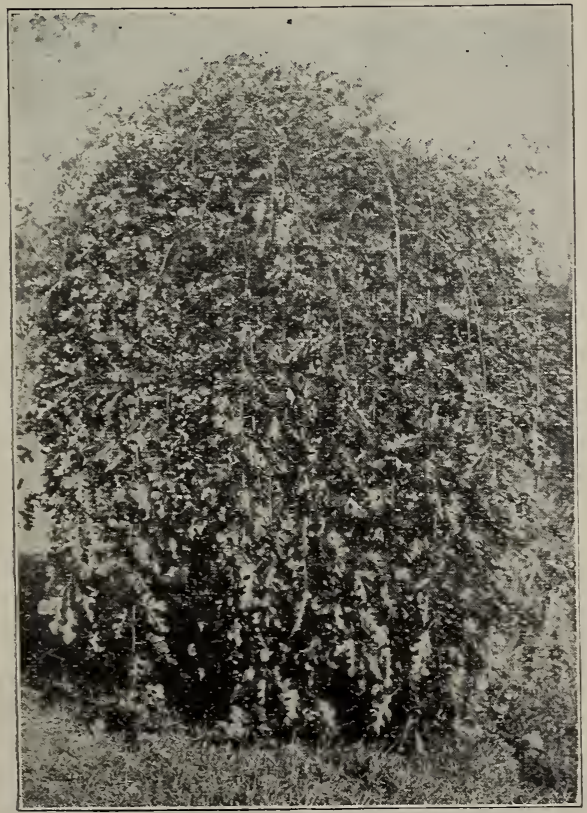

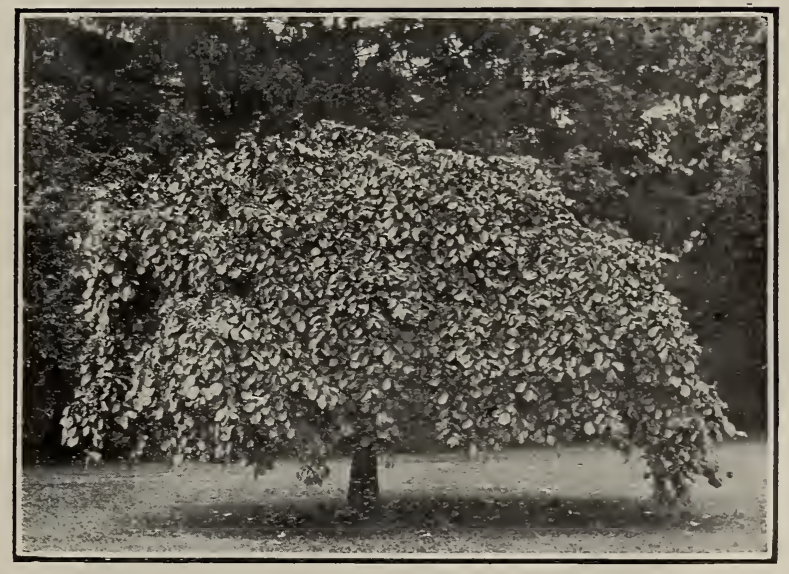

Camperdown Elm

\section{ORNAMENTAL GRASSES}

Hardy grasses are of the greatest value in lawn decoration when properly placed in the border of shrubbery or grouped in nooks and corners. The plumes form pretty winter bouquets if cut in autumn and dried.

Eulalia Zebrina. ZeBra Grass. Broad markings of gold across the leaf instead of lengthwise.

E. gracillima univitata. Foliage very narrow; airy and graceful. Any of above large clumps, $25 \mathrm{c}$ each, $\$ 1.75$ per doz. (See cut page 6). 


\section{FLOWERING SHRUBS}

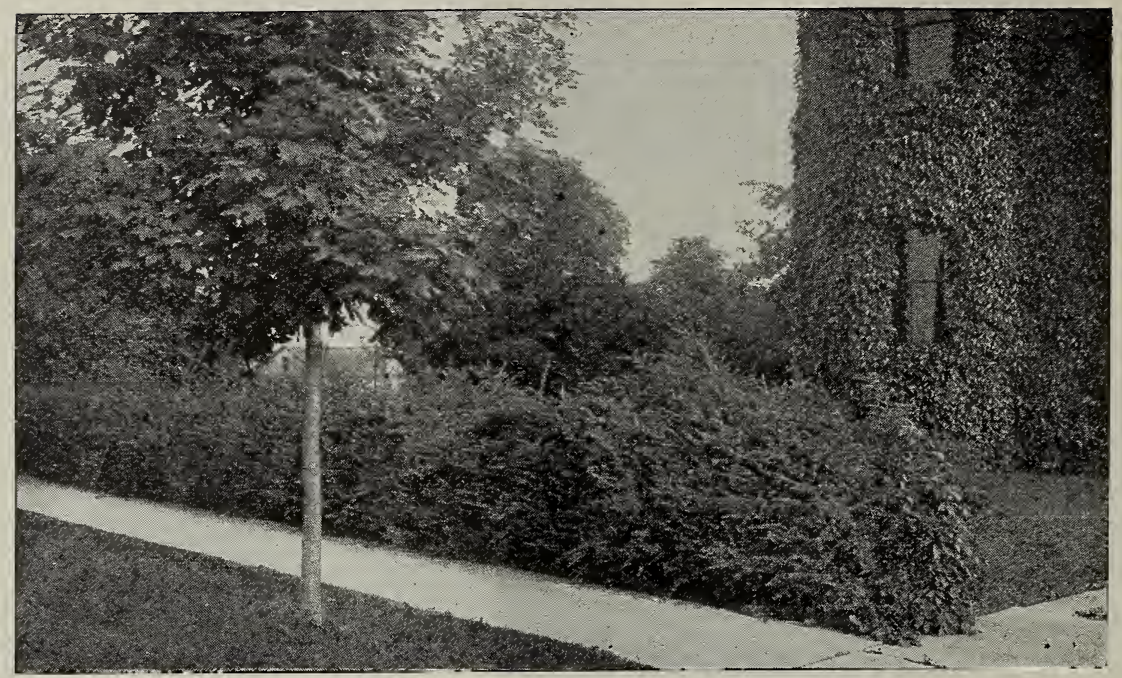

THE JAPANESE BERBERY-A FINE HEDGE PLANT

Flowering shrubs appear to best advantage when planted in groups of a dozen or more. They may also be planted to advantage singly, and by a judicious selection of varieties succession of bloom is offered all summer. In laying out new grounds, shrubs should be used extensively, as they make a beautiful display the first season. variety.

Plants we offer are all of good size and well rooted, one and one-half to six feet high, according to

Althea. Rose of Sharon. Double red, pink, purple, blue and white. These bloom from August till October. 35 cts. each, $\$ 3.00$ per doz.

A. foliis variegata Buistii. BuIST's VARIEGated Althea. 40 cts. each, $\$ 3.50$ per doz.

Amygdalus nana. Flowering Almond. Double pink- and white-flowering. 50 cts. each, $\$ 5$ per doz.

Azalea Ghent. This beautiful tribe of plants is fully the peer of the rhododendron. Flowers of nearly every shade of rose, yellow, red, etc.; very effective in groups. Strong plants with buds, 75 cts. each, $\$ 8.00$ per doz.

A. mollis. Large abundant flowers of red, yellow, salmon, cream, etc.; very fragrant. Well budded plants, 75 cts. each, $\$ 8.00$ per doz.

Berberis Illicifolia. Holly-Leaved Berberry. A rare and beautiful shrub; almost evergreen. Useful among shrubbery groups for the beautiful foliage effect. 50 cts. each, $\$ 4.50$ per doz.

B. purpurea. Foliage pure purple. $35 \mathrm{cts}$. each, $\$ 3.00$ per doz.

B. Thunbergi. Leaves purplish, suffused with a golden sheen in autumn; fruit dark crimson, remaining nearly all winter. Its glory of color and beautifully rounded form especially commend it. 25 cts. each, $\$ 2.50$ per doz., $\$ 15$ per 100 .

B. Vulgaris. Common Barberry, yellow flowers in drooping racemes in May or June followed by scarlet fruit. 25 cts. each, $\$ 2.50$ per doz.

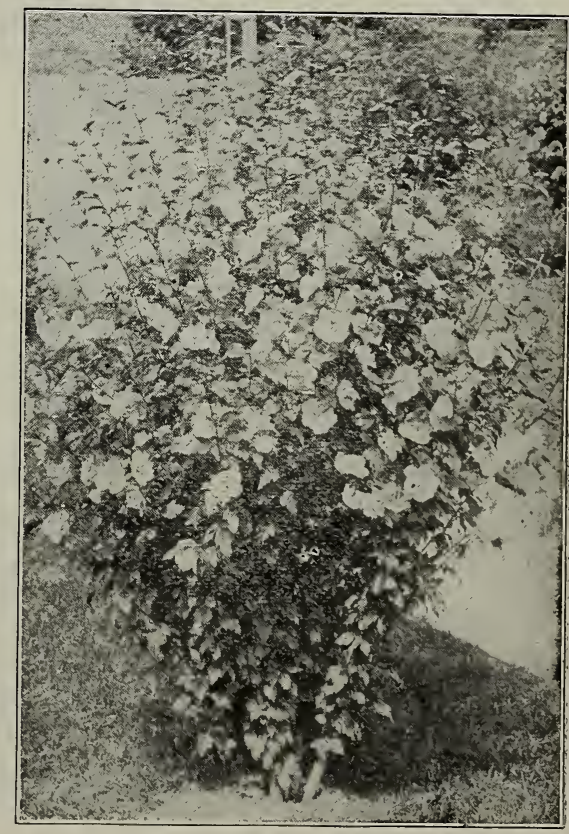

Althea, Double Pink 


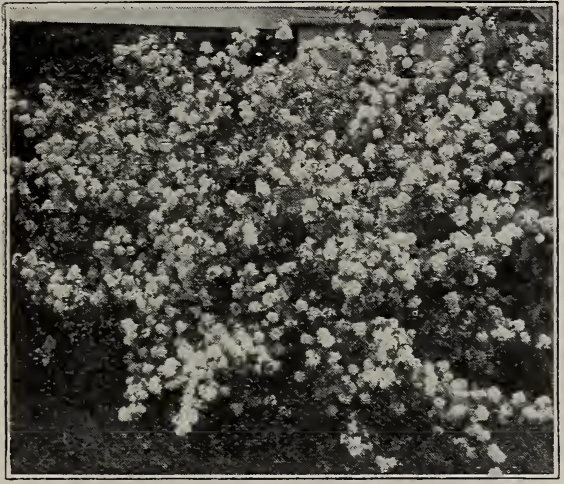

Deutzia, Lemorner

Corchorus Japonicus. Japan Globe Flower. Double, globular yellow flowers in April. 35 cts. each, $\$ 3.00$ per doz.

C. Japonicus variegatus. Dwarf; very striking silver-fringed leaves; single yellow flowers in June. 35 cts. each, $\$ 3$ per doz.

Callicarpa purpurea. Numerous brilliant purple berries in autumn. 25 cts. each, $\$ 2$ per doz.

Clethra alnifolia. Sweet Pepper-Bush. Growth low; numerous small spikes of white and very fragrant flowers in July. 25 cts. each, $\$ 2$ per doz.

Cornus sanguinea. Red-Branched Dogwood. 25 cts. each, $\$ 2$ per doz.

Corylus purpurea. PURPle Filbert or Hazel. Large, rich purple leaves. 40 cts. each, $\$ 3.50$ per doz.

Cydonia Japonica rubra. RED-FLOWERING JAPAN QUiNCE. 25 cts. each, $\$ 2.50$ per doz.

C. Japonica alba. Pure white flowers in April. 40 cts. each, $\$ 4$ per doz.

Caryopteris Mastacanthus, Blue SpIREA. A beautiful little shrub seldom seen; neat, clean habit, growing about three feet high. Flowers are produced in wonderful profusion in rich lavender-blue masses, from August until hard frosts. $40 \mathrm{cts}$. each, $\$ 3.50$ per doz.

\section{DEUTZIA}

We are indebted to Japan for this valuable genus of plants. Their hardihood, fine habit, luxuriant foliage and profusion of attractive flowers, render them the most beautiful and deservedly the most popular flowering shrubs. The flowers are produced the latter part of June in racemes four to six inches long.

Deutzia Lemoinei. A recent introduction. A1though the habit is dwarf, the flowers are large, pure white and produced freely. $30 \mathrm{cts}$. each, $\$ 3$ per doz:

D. scabra. Large, single, white flowers in June, broad leaves. 25 cts. each, $\$ 2.50$ per doz.

D. Pride of Rochester. Large, double white flowers, with the back of the petals slightly tinged with rose. 35 cts. each, $\$ 3$ per doz.
D. gracilis. A charming species of dwarf habit; flowers bell-shaped, pure white, about the first_of June. 35 cis. each, $\$ 3$ per doz.

D. gracilis rosea. Same as above except that the flowers are tinged with pink. $40 \mathrm{cts}$. each, $\$ 3.50$ per doz.

Desmodium penduliflorum. (Lespedeza Sieboldi) Japan Bush Clover. Sprays of rose-colored flowers middle of September. A magnificent plant for use in beds or groups of shrubs; though not really a shrub, it grows so strong it has come to be classed as such. 35 cts. each, $\$ 3$ per doz.

Euonymus alatus. WInged Euorymus. A remarkable species with a curious wing extending down the stems between the leaves, also bearing in peculiar fashion shining oval red berries. Foliage a beautiful reddish purple in autumn. \$1 each, $\$ 9$ per doz.

Exochorda grandiflora. Profuse, pure white flowers in May. 50 cts. each, $\$ 4.50$ per doz.

Forsythia viridissima. Flowers a light shade of yellow, opening about the third week in April. 35 cts. each $\$ 3.00$ per doz.

F. suspensa. A graceful drooping form; yellow flowers. 25 cts. each, $\$ 2.50$ per doz.

Hydrangea paniculata grandiflora. Extra strong plants, $2 \frac{1}{2}$ to $3 \mathrm{ft}$. 25 cts. each, $\$ 2.50$ per doz.

Hypericum aureum. Large, rich yellow flowers; a shrubby sort with fine narrow foliage, dwarf habit, profuse bloomer. 40 cts. each, $\$ 4$ per doz.

H. Moserianum. ST. JoHN's WorT. The finest of the species. Golden flowers $21 / 2$ inches across, blooming nearly all summer. Fine for massing or fringing shrubbery beds. Thrives well in shade. 35 cts. each, $\$ 3$ per doz.

Lonicera Morrowi. A species from Japan. A decided acquisition; strong, tupright grower;

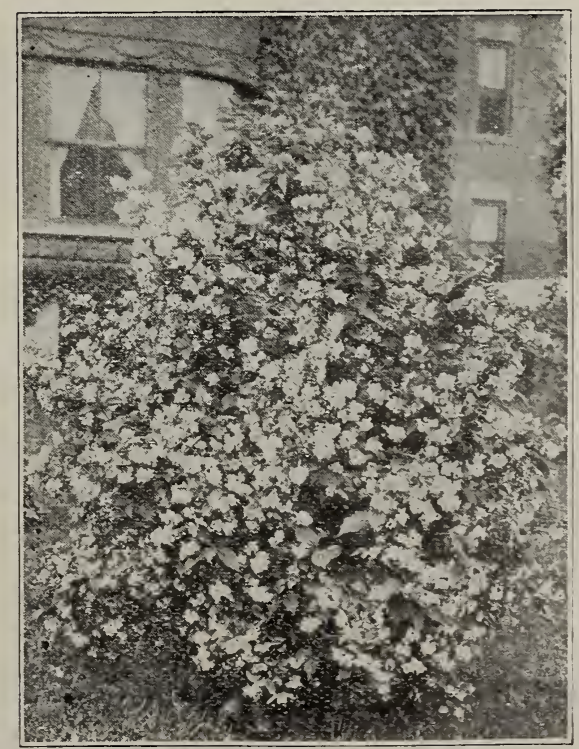

Philadelphus or Syringa 


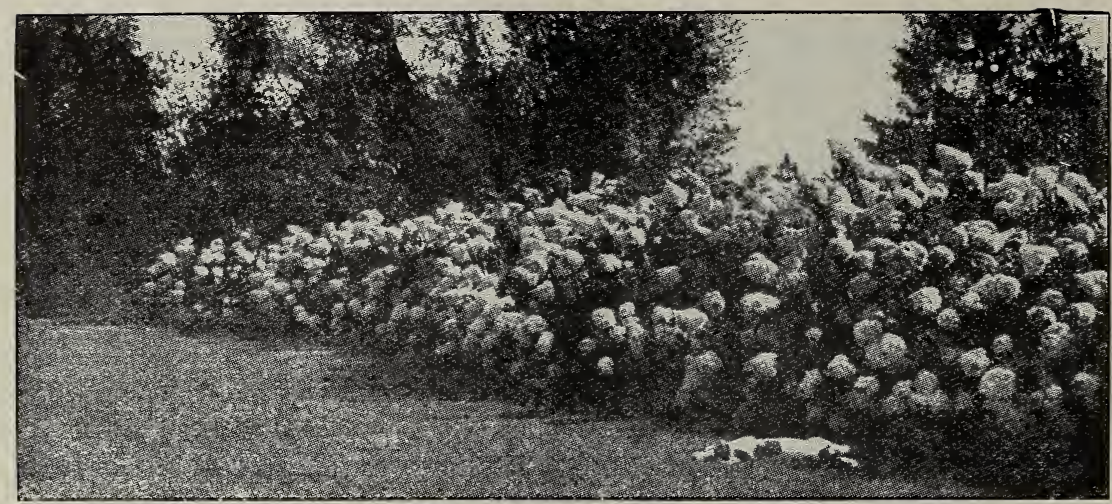

Hydrangea Paniculata Grandiflora

blooming profusely in May and June; flowers pure white, followed by bright red berries. 35 cts. each, $\$ 3.00$ per doz.

L. Tatarica. Tartarian Honeysuckle. A vigorous upright shrub, with fragrant pink or white flowers in May, followed by very ornamental orange-rcd berries. 35 cts. each, $\$ 3.00$ per doz.

L. Albertii. Low spreading growth, fine bluishgreen foliage, pinkish flowers in June. 25 cts. each, $\$ 2.50$ per doz.

Ligustrum Ibota. Japan species. Spreading habit, narrow leaves. 2 to $3 \mathrm{ft}$., 25 cts. each, $\$ 2.50$ per doz.

L. Regelianum. Heavy, spreading growth, black fruit. 25 cts. each, $\$ 2.50$ per doz.

Prinos verticillatus. Black ALdER. Very showy red berries in autumn, retained nearly all winter. 50 cts. each, $\$ 4$ per doz.

Prunus triloba. Double-Flowering Plum. Very showy pink, rosette-like flowers in early May. $3 \mathrm{ft}$., $40 \mathrm{cts}$., each, $\$ 3.50$ per doz.

Philadelphus coronarius. MOcK ORANGE, or Syringa. 3 to $4 \mathrm{ft}$., 35 cts. each, $\$ 3.00$ per doz.

P. coronarius aureus. A beautiful golden-leaved variety of the preceding; dwarf. 18 to 24 in., 35 cts. each, $\$ 3$ per doz.

Potentilla fruitcosa. ShrubBy Cinquefoll. Erect, compact habit, flowers very pretty, yellow. 30 cts. each.

Rhodotypus kerrioides. Japan. Numerous pure white flowers about May 15. 3 to $4 \mathrm{ft}$., 35 cts. each, $\$ 3.00$ per doz.

Rhus Cotinus. Purple Fringe, or Smoke Tree. 3 to $4 \mathrm{ft}$., $40 \mathrm{cts}$. each, $\$ 4$ per doz.

Syringa. Lilac. Common white and purple. 25 cts. each, $\$ 2$ per doz.

S. Charles X. Reddish purple flowers. 40 cts. each.

S. Persica. Persian Lilac. Less tree-like in form; upright shape, irregular; deep lilac flowers, holding their color well. $40 \mathrm{cts}$. each, $\$ 3.50$ per doz.

Symphoricarpus racemosus alba. WHITE WAX. Pink flowers; white ip $\times x v$ berries in fall. 35 cts. each, $\$ 3$ per doz.
S. Rubra. Indian CurRant. Branches literally covered in fall with red berries, causing them_to droop gracefully. 25 cts. each, $\$ 2.50$ per_doz.

\section{SPIRAEA (Meadow Sweet)}

These are indispensable in landscape architecture, owing to the diversity of forms, foliage, flowers and time of blooming.

Spiraea Anthony Waterer. A perfect gem in every way. It casts in the shade all 1 Spireas in brilliancy of colors; a bright crimson, and is the most profuse and persistent bloomer of them all, bearing continuously large, flat clusters of lovely bloom throughout the summer and autumn. Dwarf

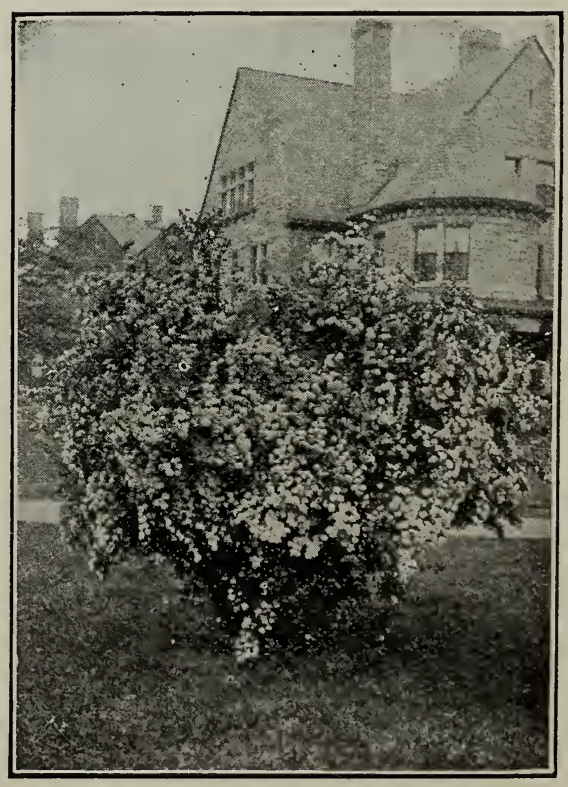

Spiraea VAN HuUtTei 
habit; comes into bloom when not over 6 inches high. 35 cts. each, $\$ 3$ per doz.

S. Arguta. One of the desirable new introductions. It resembles "Spirea Thunbergii," but is of even more slender foliage. In early May it is a perfect mass of pure white flowers. 35 cts. each, $\$ 300$ per doz.

S. Bumaldi. Ros; pink flowers. 35 cts. each, $\$ 300$ per doz

S. Collosa Alba. Dwarf white. Dense growth. 25 cts. each, $\$ 2.50$ per doz.

S. Frobelia. Similar to Anthony Waterer except that the foliage shows a finer autumn coloring. 35 cts. each, $\$ 3.00$ per doz.

S. prunifolia. BRIDAL WREATH. 35 cts. each, $\$ 3$ per doz.

S. Reveesii. A beautiful species from China. An enormous bloomer the flowers being arranged in cymes of pure white, narrow foliage, compact growth. 35 cts. each, $\$ 3.50$ per doz.

S. Rotundifolia. A rather curious straggling shrub of large size, the leaves are borne in whorls as the name implies. Rosette-like white flowers in June, 35 cts. each, $\$ 3.00$ per doz.

S. Thunbergii. Very numerous, white flowers in May; yellowish green shredded foliage, turning to bronze in autumn. 35 cts. each, $\$ 3.50$ per doz.

S. Van Houttei. The most showy Spirea. Pure white, double flowers, in such profusion as to cause the branches to droop very gracefully. 3 to $4 \mathrm{ft}$., 35 cts. each, $\$ 3.00$ per doz., $\$ 20.00$ per 100 .

Stephenandra Flexuosa. A compact-growing shrub; small, hawthorn-like leaves, bearing bunches of small, white flowers in early June. 35 cts. each, $\$ 3$ per doz.

Tamarix Africana. African TAMARISK. $30 \mathrm{cts}$. each.

T. Indica. Indian TAmarisk. Blooms in August. 30 cts. each.

Viburnum plicatum. JAPAN SNOWBall. Numerous clusters of white flowers, borne along the stem instead of at the tips. Very handsome plicated

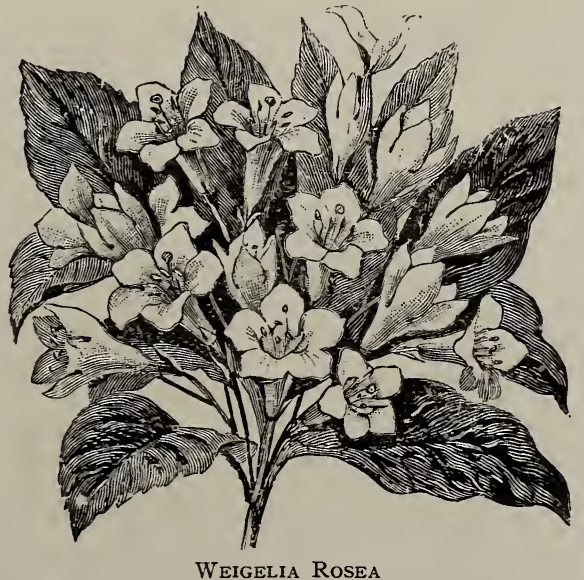

foliage, turning to rich bronze in autumn. $50 \mathrm{cts}$. each, $\$ 4.50$ per doz.

V. Opulus sterilis. Common Snowball. 35 cts. each, $\$ 3.00$ per doz.

V. Oxycoccus. White flowers in large, flat heads in May. Numerous, bright red berries in fall. 35 cts. each, $\$ 3$ per doz.

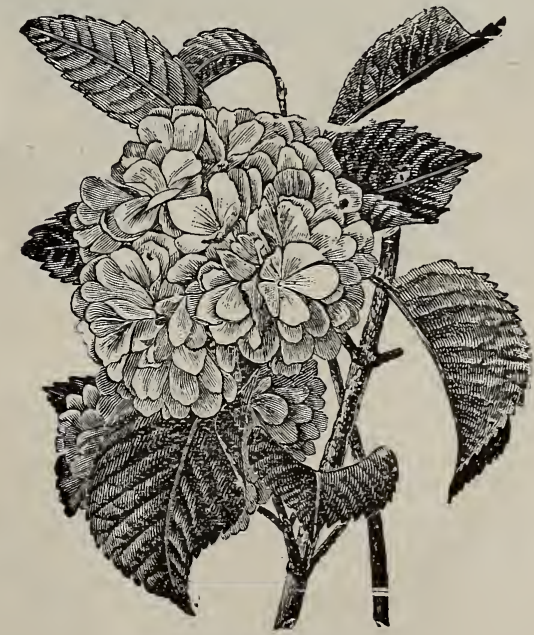

JAPANESE SNOWBaLL

Weigelia candida. Creamy white flowers. 35 cts. each.

W. variegata. Leaves handsomely variegated with golden; light pink flowers in great profusion. 35 cts. each, $\$ 3.50$ per doz

W. Lavallei. Dark, reddish purple flowers in June, and less abundant during summer. 35 cts. each, $\$ 3.50$ per doz. 
W. Rosea. Rose colored flowers in great profusion in June. 35 cts. each, $\$ 3.00$ per doz.

Eva Rathke. The best red Weigela flowers, fine dark red, blooms all summer. 40 cts. each, $\$ 4$ per doz.
Yucca filamentosa. AdAm's NeEdLE. Valuable for rockwork; large plants. 25 cts. each, $\$ 2$ per doz.; very heavy plants, 50 cts. to $\$ 1$ each.

"If you fail to find what you want ask us about it, we can undoubtedly supply you."

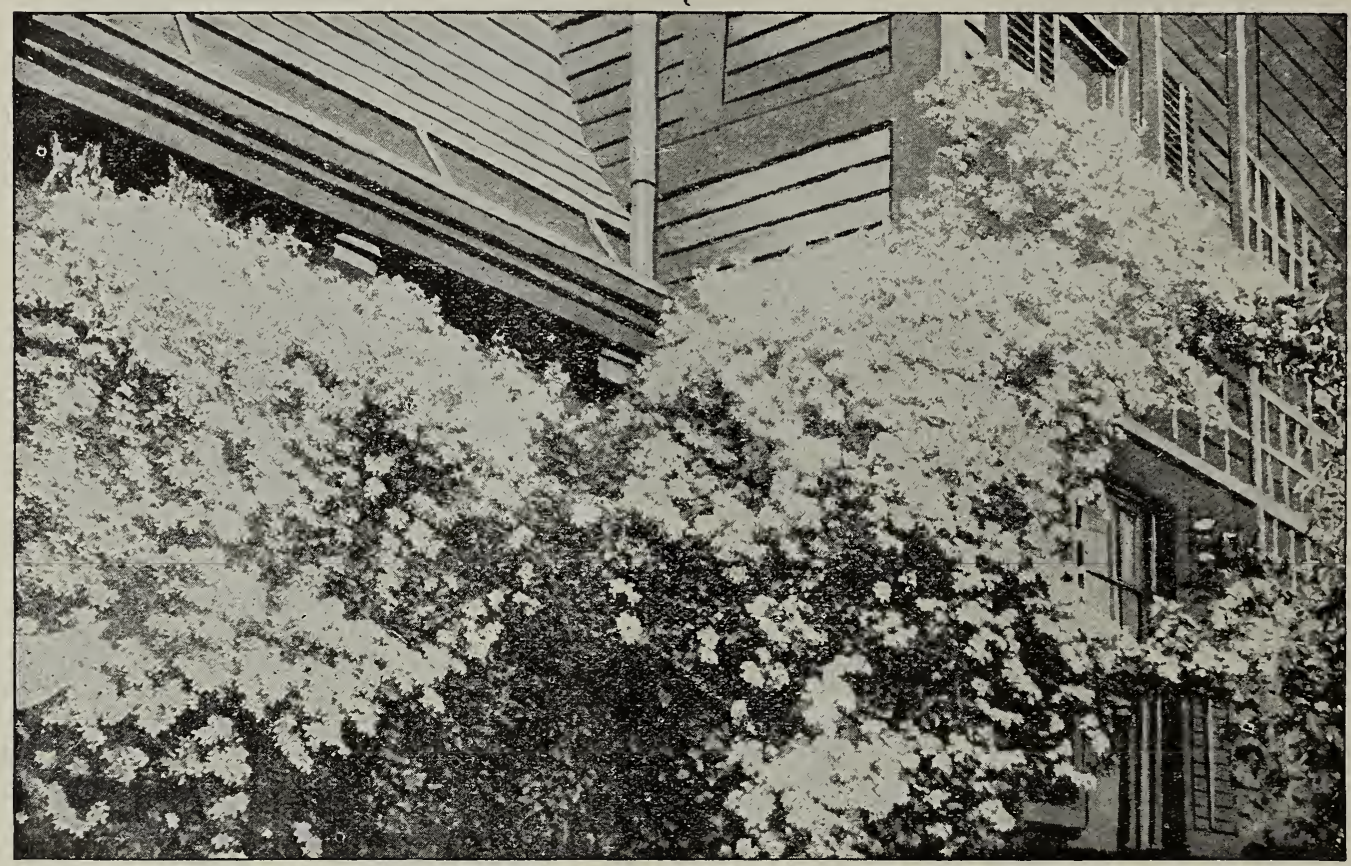

CLEMATIS PANICULATA

\section{CLIMBING VINES}

Ampelopsis Veitchi. JaPAN Ivy. The best vine for covering stone or brick-work. Strong 2-year plants, 25 cts. each, $\$ 2.50$ per doz., $\$ 15$ per 100 .

A. quinquefolia. Virginia CREePER. Strong plants, 25 cts. each, $\$ 2$. per doz.

Akebia quinata. Small, shining; sub-evergreen leaves. Small, purple, very fragrant flowers in June. 25 cts. each, $\$ 2$ per doz.

Bignonia radicans. Trumpet Vine. 25 cts. each, $\$ 2$ per doz.

Clematis Duchess of Edinburgh. Best double white; fragrant. 60 cts.

C. Jackmani. Large, dark purple flowers. 50 cts. each, $\$ 4$ per doz.

C. Mad. Edouard Andre. New. Large, clear red. 60 cts. each, $\$ 6$ per doz.

C. paniculata. Of strong, vigorous growth. Flowers white, star-shaped. Very fragrant. Strong plants, 25 cts. each, $\$ 2.50$ per doz.

Euonymous radicans. Foliage evergreen, often edged with silver; very hardy. Useful in shaded places. Strong plants, 25 cts. each, $\$ 2.50$ per doz.

E. radicans variegata. An evergreen creeper with silvery variegated leaves. 25 cts. each, $\$ 2.50$ per doz.
Hedera Helix. ENGLISH Ivy. Strong plants. 25 cts. each, $\$ 2.50$ per doz.

Kudzu. A Japanese vine with very large light green leaves. Most rapid growing of the vines. Strong roots. $50 \mathrm{cts}$. each.

Lonicera Halliana. Hall's Honeysuckle. Yellow and white flowers nearly all summer; very fragrant; nearly evergreen. 25 cts. each, $\$ 2$ per doz., $\$ 15$ per 100 .

L. Japonica variegata. Foliage variegated with gold and white; beautiful autumn tints. 25 cts. each, $\$ 2$ per doz.

L. sempervirens. Scarlet Trumpet HoneySUCKLE. Scarlet flowers all summer; very desirable. 35 cts. each, $\$ 3$ per doz.

Periwinkle. Sometimes called Myrtle. Bright green, glossy leaves, retained all winter; clear blue flowers in April and May. 20 cts. each, $\$ 1.25$ per doz., $\$ 7.00$ per 100 .

Wistaria Multijuga. JaPAnEse Wistaria. Flowers light purple. $50 \mathrm{cts}$. each, $\$ 4$ per doz.

W. Sinensis. Chinese Wistaria. Best of all. Purplish white flowers in May. 40 cts. each, $\$ 3.50$ per doz.

W. Sinensis alba. A rare sort with pure white flowers. 50 cts. each, $\$ 5$ per doz. 


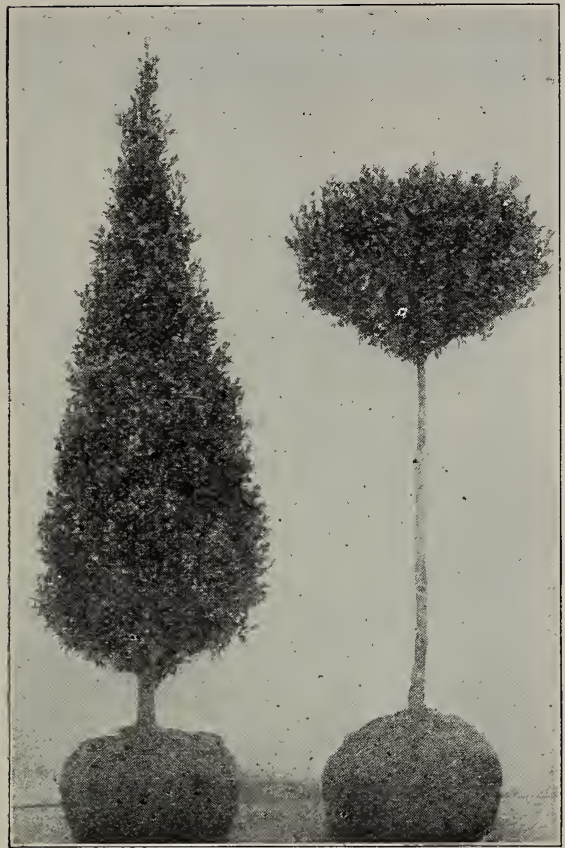

Boxwood (Buxus)

\section{EVERGREEN SHRUBS}

Azalea amoena. A dwarf shrub with small dark green leaves, changing to bronze in winter. Numerous dark red or claret-colored flowers in May. Strong plants, $\$ 1.00$ each.

Kalmia latifolia. Mountain Laurel. 18 to 24 in., $\$ 1.00$ each, $\$ 10$ per doz.; large bushy plants $\$ 1.50$ to $\$ 3$.

Mahonia aquifolia. Holly-LeAved MAHonia. Shiny green, prickly leaves, turning to bronze and red in autumn; clusters of yellow flowers in May. 16 to 24 in., 40 cts. each, $\$ 4$ per doz.

Rhododendrons. A relative of the Laurel, but larger flowers in larger clusters of various shades of red, purple and white. We offer only such sorts as have proven hardy in this climate. Plants, 18 to 24 in., with buds, $\$ 1.50$ each, $\$ 15$ per doz.; large plants $\$ 2$ to $\$ 5$ eaวh.

\section{BOXWOOD (Buxus)}

These beautiful evergreen shrubs have become very popular for formal planting and for decoration in tubs.

The foliage is thick and glossy dark green, and holds its color best of any evergreen. Bears pruning with impunity. Can be grown in any shape or form.

The Sempervirens or Tree Box is perhaps the best of the large growing species. It is absolutely hardy. We offer a fine stock of the various forms.

Pyramidal. 3 to $3 \mathrm{I} / 2 \mathrm{ft} ., \$ 1.50$ to $\$ 2.50$ each; $4 \mathrm{ft}$, $\$ 3.00$ to $\$ 5.00$.

Bush Form. $2 \mathrm{ft} ., \$ 1.25$ each; $21 / 2 \mathrm{ft} ., \$ 1.75$ each.

Standard. Stems about $2 \mathrm{1} / 2 \mathrm{ft}$, heads 18 inches to3 ft. $\$ 3.00$ to $\$ 8.00$ each.

\section{EVERGREENS}

\section{ABIES (Fir)}

Abies Concolor. Silver Fir. Heavy foliage of a bluish gray tinge. Strong erect grower, making a fine large tree. $2 \mathrm{ft}$., $\$ 1.50$ each, 3 to $4 \mathrm{ft}$., $\$ 3$ to $\$ 5$ each.

A. Nordmaniana. Nordman's FIR. Heavy thick foliage of a beautiful dark glossy green, an elegant tree, making a large tree eventually. $2 \mathrm{r} / 2$ to 3 ft., $\$ 2.00$ each. Larger specimens priced on application.

\section{JUNIPERS}

Juniperus Canadensis. Low growth; spreading open head; pale green foliage; choice. 18 to 24 in., 75 cts. each.

J. Canadensis aurea. A beautiful golden variety of the above. 18 in., $\$ 1.25$ each

J. Hibernica. IrIsH Juniper. Very close, upright, slender growth, with a silvery glaucous appearance. $3 \mathrm{ft}$., $\$ 1$ each, $\$ 9$ per doz.

J. Japonica Aurea. Golden Japanese Juniper. Rather spreading and eccentric in growth, very striking. Beautiful for rock work or other places where contrasts of colors are wanted. Good strong plants. $\$ 1.50$ each.

J. Sabina. SAVIN JUNIPER. Low growth; widespreading; dark green foliage; well adapted for rockwork and hillsides. 75 cts. each, $\$ 8$ per doz.

J. Suecica. Swedish Juniper. A little more spreading and foliage a brighter green than J. Hibernica. $3 \mathrm{ft}$., $\$ 1$ each, $\$ 9$ per doz.

J. Virginiana. RED CEDAR. Very tall narrow compact growth. Fine plants. 3 to $4 \mathrm{ft}$., $\$ 2$ each, 4 to $5 \mathrm{ft}$., $\$ 3$ to $\$ 5$ each.

J. var. Glauca. Blue Red Cedar. Same as above, only with beautiful blue-green foliage. Rare and very choice. 2 to $3 \mathrm{ft}$., $\$ 2.00$ each, 3 to 4 ft., $\$ 3.00$ to $\$ 4.00$ each.

\section{RETINOSPORA (Japan Cypress)}

A most interesting class of evergreens, many of them being of dwarf habit and adapted to small places. There are many varieties of tints and variegation among them, and they are all easily transplanted and perfectly hardy.

Retinospora ericoides. HEATH-LIKE JAPAN Cypress. Conical, compact form. 2 to $2 \mathrm{I} / 2 \mathrm{ft}$., $\$ 1$ each; $3 \mathrm{ft}$. specimens $\$ 2$.

R. filifera. THREAD-BRANCHED JAPAN CyPRESS. A beautiful tree, with bright green foliage. It is particularly graceful, as the ends of its shoots droop in long filaments. 2 to $3 \mathrm{ft}$., $\$ 2.25$ each; 4 to $5 \mathrm{ft}$., $\$ 4$ to $\$ 6$.

R. filifera aurea. GOLdEN THREAD-BRANCHED JAPAN Cypress. One of the handsomest of the family. It has all the gracefulness ofthe last and branches of a beautiful golden $\$ 1.50$ to $\$ 3$ each. 
R. Obtusa. Thick, dark green foliage. $2 \mathrm{ft}$., $\$ 1.50$ each.

R. obtusa nana. A weird little tree of irregular, picturesque growth, and black-green foliage. Dwarf. 18 in., $\$ 2$ each.

R. obtusa nana aurea. Same as above, with beautiful golden foliage. $\$ 2.50$ each.

R. pisifera aurea. Bright golden flat, wavy foliage. $3 \mathrm{ft}$., $\$ 2.50$ each.

R. plumosa. Plum-Like Japan Cypress. 2 ft., $\$ 1.50$ each; $3 \mathrm{ft}$., $\$ 2$ to $\$ 3$ each.

R. plumosa aurea. Golden Plume-Like Japan Cypress.

Its shoots are bright golden tinted through the year; unsurpassed for massing. $2 \mathrm{I} / 2$ to $3 \mathrm{ft}$., $\$ 1.50$ to $\$ 3$ each; 3 to $4 \mathrm{ft}$., $\$ 2$ to $\$ 5$ each.

R. squarrosa. Soft bluish green foliage. $2 \mathrm{ft}$., $\$ 1.25$ each, $3 \mathrm{ft} ., \$ 2.50$ each.

Picea alba. White SPRuce. Compact pyradmial form; bluish foliage. 4 to $5 \mathrm{ft}$., $\$ 2.25$ each; 2 to $3 \mathrm{ft}$., $75 \mathrm{cts}$. each, $\$ 6$ per doz.

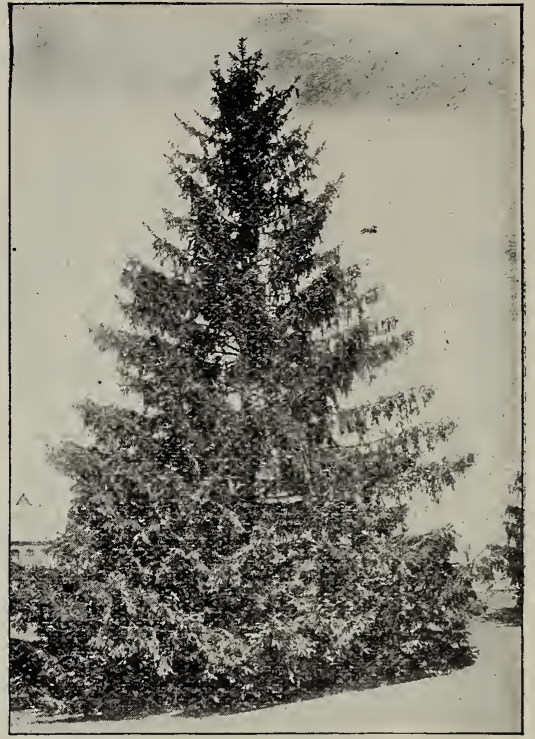

NORWAY SPRUCE

P. Douglasii. Douglas Spruce. Conical form: branches numerous, spreading horizontally; leaves light green above, glaucous below. 2 to $3 \mathrm{ft}$., $\$ 2$ to $\$ 3$ each; 3 to $4 \mathrm{ft}$., $\$ 3$ to $\$ 5$ each.

P. excelsa. Norway Spruce. Well-furnished trees. 4 to $5 \mathrm{ft}$., $\$ 1.50$ to $\$ 5$ each; 3 to $4 \mathrm{ft}$., 75 cts. to $\$ 3$ each; $\$ 8$ to $\$ 20$ per doz.; 2 to $3 \mathrm{ft}$., $25 \mathrm{cts}$. to $75 \mathrm{cts}$. each, $\$ 2.50$ to $\$ 8$ per doz. Prices per 100 given on application.

P. pungens Kosterii. Colorado BLUE SPRUCE. Moderately dense growth and pyramidal form like the White Spruce; foliage of a rich blue or sage color. $2 \mathrm{ft}$., $\$ 2.50$ each; $3 \mathrm{ft}$., $\$ 4$ to $\$ 5$ each; $4 \mathrm{ft}$., $\$ 6$ to $\$ 7$ each.

P. Nigra. B L A C K SPRuce. Very dark bluish green. 2 to $3 \mathrm{ft}$., $\$ 1$ each, 3 to $4 \mathrm{ft}$., $\$ 2$ to $\$ 4$ each.

P. orientalis. ORIENTAL or EASTERN SPRUCE. Fine dark green foliage; more dense than Norway, somewhat slower growth; an elegant lawn tree. 2 to $2 \mathrm{r} / 2 \mathrm{ft}$., $\$ 1.50$ to $\$ 2.50$ each; 3 to $3 \mathrm{r} / 2$ ft., $\$ 3$ to $\$ 5$ each.

Pinus Strobus. White Pine. 4 to $5 \mathrm{ft} ., \$ 2.50$ each; 3 to $4 \mathrm{ft}$., $\$ 1$ each, $\$ 10$ per doz.

P. Cembra helvetica. Swiss Stone PINE. A handsome conical tree, with dark green thick, foliage. 2 to $3 \mathrm{ft}$., $\$ 2$ each.

P. Mughus. Mugho Dwarf Pine. Low-growing, broad, spreading; more of a large pine bush than a tree; goodsized plants. $\$ 1.50$ each.

P. Austriaca. AUstrian Pine. Large, roundish form; dark glossy leaves. 4 to $5 \mathrm{ft}$., $\$ 3$ each; 3 to $4 \mathrm{ft}$., $\$ 2$. 


\section{THUYA (Arborvitae)}

Thuya American. 2 to $3 \mathrm{ft}$., $60 \mathrm{cts}$. each, $\$ 5$ per doz.; 4 to $5 \mathrm{ft}$., $\$ 2$ each.

Th. elegantissima aurea. Rollinsox's Goldex ARBORVITAE. Bright golden, changing to a beautiful copper in autumn. $2 \frac{1}{2}$ to $3 \mathrm{ft}$., $\$ 1.50$ each.

Th. Globosa. Dwarf; globe-shaped. 15 to 18 in., $\$ 1$ each.

Th. occidentalis aurea. PEABody's ARborvitaE. Campact, pyramidal form; very bright golden foliage. 2 to $2 \mathrm{x} / 2 \mathrm{ft}$., $\$ 1.50$ each.

Th. occidentalis Ellwangeriana. Tом Тнимв ARBorvitae. Somewhat dwarf, but making a larger tree or bush than Globosa; very compact; dark green foliage. $2 \mathrm{ft}$., $\$ 2.00$ each.

Th. pyramidalis. Pyramidal Arborvitae. 3 to $4 \mathrm{ft}$., \$1.50 each.

Th. Siberian. Slow growth; very compact; pyramidal form. 2 to $3 \mathrm{ft}$., $\$ 1.50$ each.
TSUGA

Tsuga Canadensis. Hemlock Spruce. Spraylike foliage, distinct from all other trees. 4 to $5 \mathrm{ft}$.,

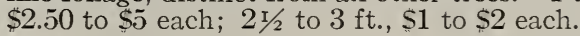

\section{TAXUS (Yew)}

Taxus baccata. ExGLISH Yew. A charming tree with rich, dark glossy green foliage. $\$ 1.25$ each.

T. Hibernica. IRISH YEw. Very compact pyramidal growth the best of the large growing yews. Absolutely hardy. Fine plants, 2 to $3 \mathrm{ft}$., $\$ 2.50$ each.

T. Hibernica aurea. $2 \mathrm{ft} ., \$ 2.00$ each.

\section{DECIDUOUS HEDGE PLANTS}

Privet, California. The best all-round hedge plant. Plants we offer are extra stocky and exceedingly well rooted. 2 to $2 \mathrm{x} / 2 \mathrm{ft}$., $\$ 4.50$ per 100 , $\$ 40$ per 1000 ; 18 to 24 in., $\$ 3.50$ per 100 .

Berberry Thunbergii. \$15 per 100, \$120 per 1000 .

For larger or smaller sizes than those mentioned above, or evergreens for screens and hedges, write for special prices

\section{SPECIMEN EVERGREENS}

Having given special attention to growing extra fine evergreens to supply a growing demand for something a little finer than usually sent out, we are now prepared to furnish some extra-fine specimens of many of above varieties in sizes from 2 to 8 feet high. These have been sheared frequently, and are exceptionally fine for immediate effect. Prices given on application.

\section{HARDY HERBACEOUS AND BULBOUS PLANTS}

Astilbe Japonica. (SPIRAEA Japonica.) Strong clumps, 25 cts. each, $\$ 2$ per doz.

Asters. Assorted. Strong, \$1.25 per doz., \$12 per 100.

Bleeding Heart. 20 cts. each, $\$ 2$ per doz.

Chrysanthemums, Pompon (Artemesias). 15c ts. each, $\$ 1.50$ per doz.

Delphineum. LaRkspur. Strong plants. 20 cts. each, $\$ 1.50$ per doz.

Digitalis. Fox-Glove. 20 cts. each, $\$ 1.50$ per doz.

Herbaceous Peonies. Red, white and pink. Extra strong, 35 cts. each, \$3 per doz.

Hollyhocks. Assorted, single $\$ 1.75$ per doz. Double sorts, $\$ 2$ per doz.

Hibiscus. Marsh Mallow, Crimsox Eye, and other common sorts, $\$ 2.50$ per doz.

Iris. Hardy sorts, 15 cts. each, $\$ 1.50$ per doz.

Jonquils and Narcisus, bulbs. 50 cts. per doz.,\$3 per 100 .

Lily-of-the-Valley. Pips. 60 cts. per doz., \$4 per 100 .

Phlox, Assorted Varieties. $15 \mathrm{cts}$. each, $\$ 1.50$ per doz.

- P. subulata. Moss PINk. Evergreen moss-like foliage; grows about 6 inches high; strong clumps, $15 \mathrm{cts}$. each, $\$ 1.50$ per doz.

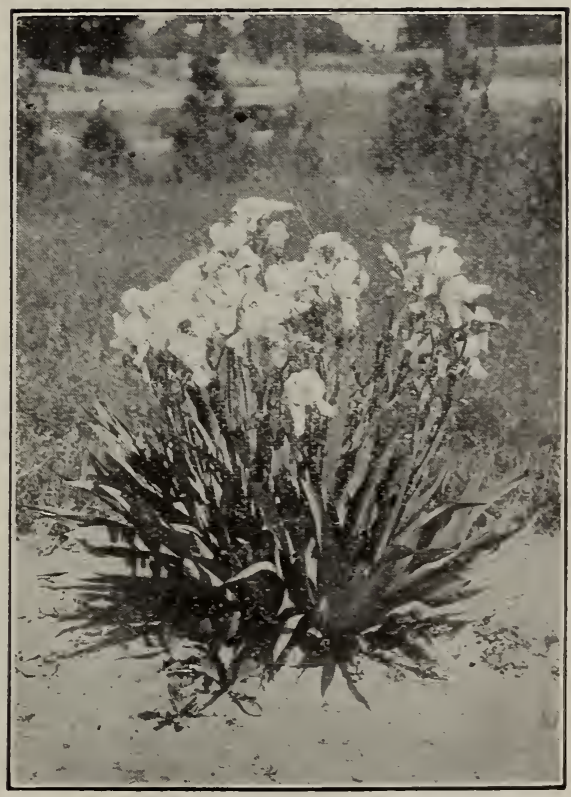




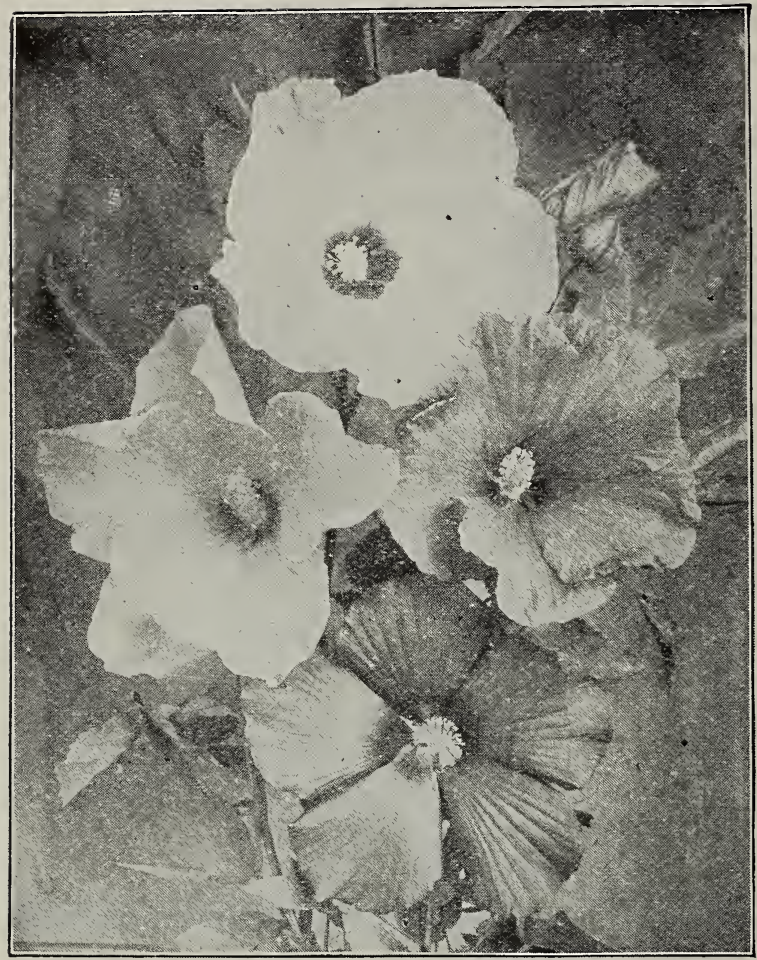

Mallow Marvels

\section{HARDY ROSES}

We offer below a select list of such sorts as have been found to be hardy in this climate, and that have proven satisfactory to grow out of doors. Plants we offer are strong two and three years old, except where noted, and will bloom the first season.

Price, except where noted, 30 cts. each, $\$ 3.00$ per doz., $\$ 20.00$ per 100. Extra large plants $35 \mathrm{cts}$. each. $\$ 3.50$ per doz.

\section{HYBRID PERPETUALS}

The word "perpetual" is perhaps, somewhat misleading, as only a few sorts under this head are really perpetual. i Those marked with a star $\left(^{*}\right)$ bloom practically from June till frost.

*Anne de Diesbach. Bright, clear pink, large and full.

General Jacqueminot. Bright crimson-scarlet; very free bloomer.

*Mme. Gabrielle Luizet. Delicate silvery pink, heightened at the center; elegant in bud.

*Mrs. John Laing. Delicate pink; fine form, especially in bud; without doubt the best bloomer among this class of Roses; very fragrant. $35 \mathrm{cts}$.

Margaret Dickson. New. Creamy white; extra large and fine.

*Ulrich Brunner. Bright cherry-red.
Mallow Marvels. Most brilliant new production of scientific plant breeding. Immense flowers 8 to 10 inches across in fiery crimson, rich blood-red, soft shell pink and clear snowy white. They surpass all other perennials in profuseness of bloom and brilliancy of color. From July until frost, the flowers continue to appear in profusion. Absolutely hardy, of herbaceous character they come up year after year under varied conditions.

These wonderful Mallows have deservedly become one of the most if not the most popular of Herbaceous hardy plants, so that the demand has increased so rapidly that last season we sold five times the number we did the season before.

We have a fair supply for this season but we advise ordering early to be sure of getting colors wanted and before the supply is exhausted. Strong plants, two and three years old which will bloom the first season. 50 cts. each, $\$ 5$ per doz.

Tritoma. (Red Hot Poker Plant.) Strong plants, 20 cts. each, $\$ 2$ per doz.

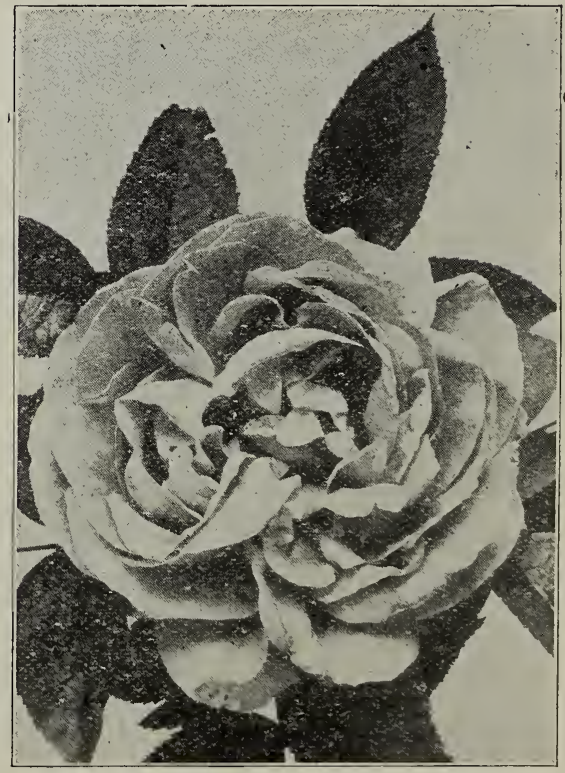

Anne De Diesbach

*Paul Neyron. Large dark rose.

*Marshall P. Wilder. Crimson vermilion. 35 cts.

*Frau Karl Druschki. Fine white, long pointed buds, plant a vigorous grower, good bloomer. $35 \mathrm{cts}$.

*Perles des Blanches. White, changing to flesh color. 35 cts. 
*Gruss au Teplitz. Crimson, absolutely everblooming.

*Mamon Cochet. Pink; buds long and pointed, 40 cts.

*Mamon Cochet. White, with slight pinkish tinge. $40 \mathrm{cts}$.

\section{SUMMER ROSES}

Persian Yellow. Bright yellow.

Harrison Yellow. A little fuller than above.

\section{MOSS ROSES}

Salet. Pale rose; a good autumn bloomer.

Crested. Rose color; buds beautifully formed and very mossy.

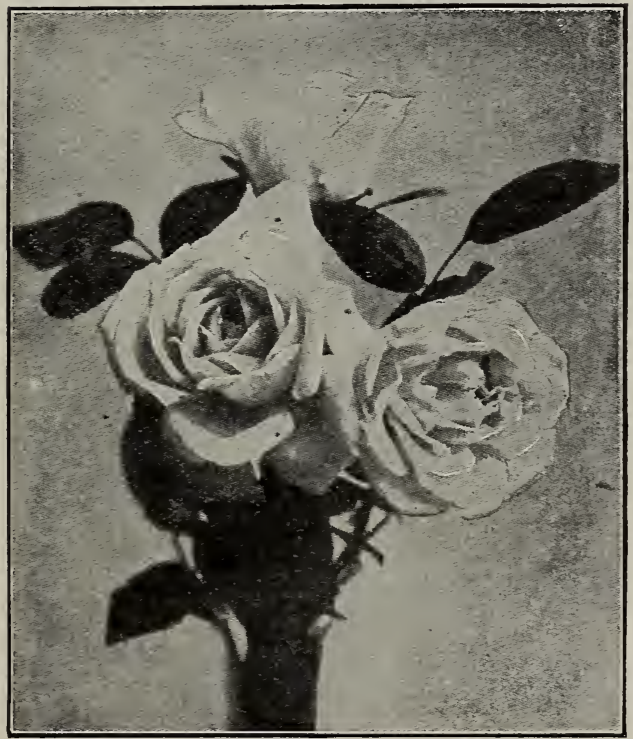

Frau KarL Druschki

\section{HYBRID TEAS}

These should be protected in winter with leaves or litter. They are all constant or perpetual bloomers. Strong, field-grown plants, 35 cts. each, $\$ 3$ per doz.

Chas. Dingee. An elegant new pink rose; long pointed buds, large and full when open. Holds its color well. Deliciously perfumed. 50 cts.

Duchess of Albany. New. A sport from La France, which it closely resembles, except that t $t$ is darker.

LaFrance. Beautiful silvery rose color, lightest inside; beautiful in the bud.

Kaiserin Augusta Victoria. This is one of the finest and largest white Roses; buds large size. long and pointed.

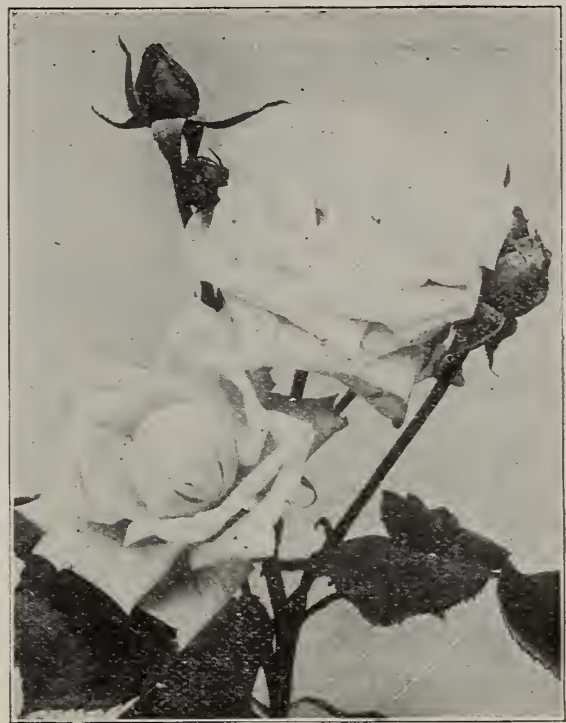

La France

\section{POLYANTHA ROSES}

These are of great value for bedding, as they give a mass of bloom from June till November. Their habit is dwarf; flowers small, produced in large clusters.

Clothilde Soupert. Flowers large, very double; pearly white, shaded with pink toward center.

Pink Soupert. A beautiful pink, blooms constantly. 30 cts. each, \$3 per doz.

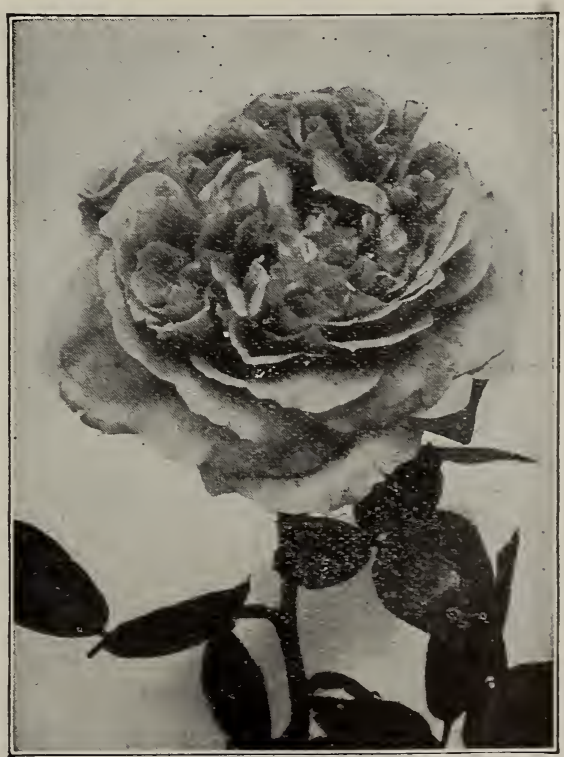

Paul Neyron 


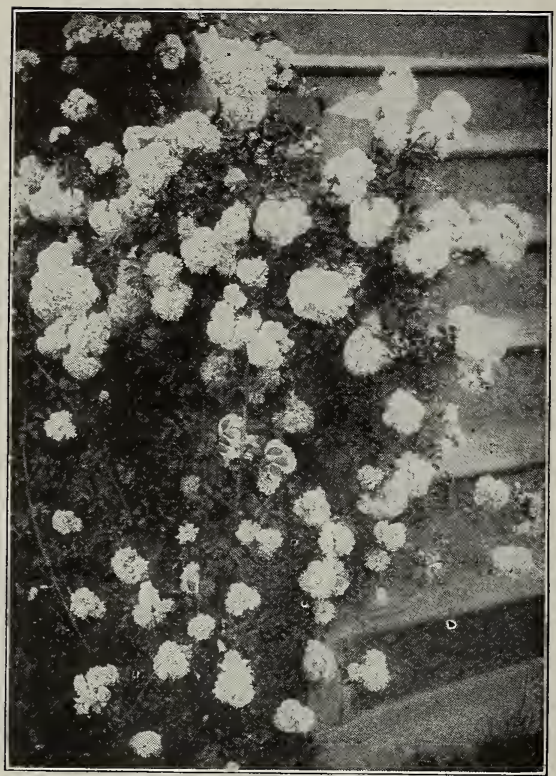

Dorothy Perkins

\section{NEW HYBRID POLYANTHA OR BABY RAMBLERS}

These beautiful little Roses have grown wonderfully in favor since their introduction a few years ago. They are usually called Baby Ramblers, though they are all dwarf bush Roses. Strong plants, 30 cts. each, $\$ 3$ per doz.

Crimson Baby. The first of these sorts to be introduced and the most popular. Absolutely ever blooming.

Pink Baby. Small pink flowers in clusters.

White Baby. Small white flowers in clusters.

\section{RAMBLER ROSES}

Crimson Rambler. Strong, field-grown plants, 35 cts. each, $\$ 3$ per doz.; extra large plants, 60 cts. each.

Yellow Rambler. Similar in all respects to Crimson Rambler, except color, which is a clear, decided yellow in the bud, changing to cream when open. Strong plants, 35 cts. each, $\$ 3$ per doz., extra size, 75 cts. each.

Dorothy Perkins. Another grand Rambler; flowers double, borne in clusters, of a beautiful rosepink; a good bloomer. 35 cts. each, $\$ 3$ per doz.

Philadelphia Rambler. An improvement on the Crimson Rambler. 35 cts.

\section{ROSA RUGOSA}

\section{JAPANESE ROSE}

A valuable species for grouping. It is a particularly attractive bush, with its dense mass of large glossy leaves, which have a peculiar wrinkled appearance. Flowers 3 to 4 inches across, single, rosy red or white, followed by bright scarlet fruits. Strong, field-grown plants, 35 cts. each, $\$ 2.50$ per doz., $\$ 20$ per 100.

Rosa Wichuraiana. The single, white Memorial Rose. A creeping species; flowers small, pure whiteg very fragrant; foliage bright glossy green. Valuable for covering banks, stumps, rockeries etc. Established plants make a growth of ten to twenty feet in a season. It will grow in very poor soil. Stronfield-grown plants, 25 cts. each, $\$ 2.50$ per doz.

\section{MANDA'S NEW HARDY HYBRID WICHURAIANA ROSES}

These keep the same trailing habit, freedom of growth and fine glossy green foliage as the parent form. They produce innumerable quantities of large, well-formed blooms, lasting a long time in perfection. Like Rose Wichuraiana, they will grow in any soil, even on poor sandy or gravelly banks.

Strong, field-grown plants, of any of the following, $25 \mathrm{cts}$. each, $\$ 2.50$ per doz.

For larger quantities, please write for prices

Manda's Triumph. Large clusters of wellformed double, pure white, fragrant flowers, two inches across.

Universal Favorite. Double flowers of a beautiful rose-color, over two inches across; fragrant.
South Orange Perfection. Double flowers, nearly two inches across. Soft blush-pink at tips, changing to white.

Pink Roamer. Single flowers; bright pink; orange-red stamens; very fragrant.

\footnotetext{
"After careful selection we now have shade trees, which are growing very well and in every way satisfactory. Thank you for your courtesies in the matter.
ScARSDALE ESTATE, Scarsdale, N. Y.

"The box of Shrubs arrived in good order, and are very satisfactory in every way."

"The 000 Privets H. C. Wadsworth, Manchester, Conn. they would be." Prof. Alex. Oldrini, I92 Broadway, N. Y.
} 


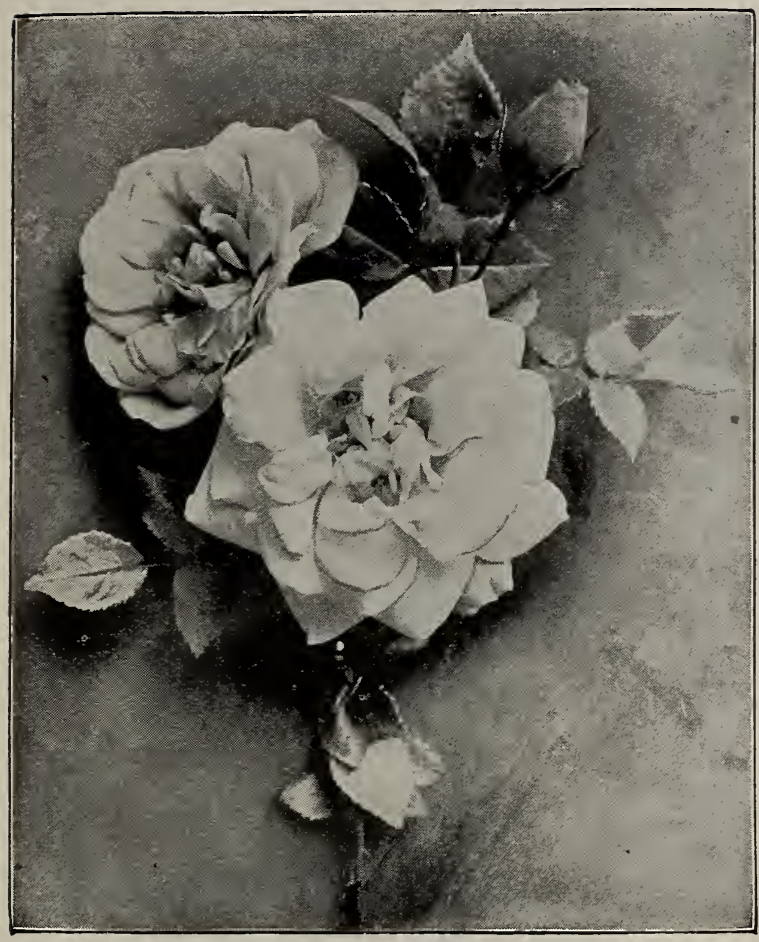

EVERGREEN ROSE GARDENIA

\section{ANOTHER NEW SET OF HYBRID WICHURAIANA ROSES}

A remarkable new set of Roses, of wonderfully free growth, a single specimen four years old covering a space of 240 square feet, with shoots 12 to 25 feet in length. The foliage of all is leathery in texture, glossy, and not only free from insects, but nearly evergreen. The large fragrant flowers are produced very freely, and are extremely useful for cutting purposes.

Jersey Beauty, Wichuraiana X, Perle des Jardins. Large single flowers, three inches in diameter; opening pale yellow.

Evergreen Gem. Wichuraiana X, Mme. Host. Foliage rich, bronze color, closely matted; flowers produced singly on stems; yellow, buff in bud, opening almost white, 2 to 3 inches in diameter; perfectly double, with delightful sweet brier fragrance.

Gardenia, Wichuraiana X, Perle des Jardins. Flowers produced single on stems six inches to one foot long; bright yellow in bud, cream-color when open; about three inches across. Strong plants, 35 cts. each, $\$ 3$ per doz.

Our Roses are all Strong Field Grown Plants and worth the money. They are not to be compared with cheap mailing sizes.

\section{Additional list of the more desirable $40 \mathrm{cts}$. each, \$4 per doz. except as noted.}

Roses of recent introduction,

Betty. A grand Rose, of splendid form, large and full, color coppery-rose, deliciously perfumed. $50 \mathrm{cts}$.

Golden Cochet. Clear sulphur-yellow, large and full, perfectly formed, very free and constant. 45 cents.

General Mac Arthur. Color brilliant scarlet.Fine form and good bloomer. 35 cts.

Jonkheer J. L. Mock. This grand Rose is the strongest growing in the Hybrid Tea class. Theblooms are very large, produced in great profusion on stiff erect stems, of perfect form and highly perfumed. Color clear imperial pink. $50 \mathrm{cts}$ each,

Killarney. Pink. A grand pink Rose, always in bloom.

Killarney. White. Also a satisfactory bloomer.

Mrs. Aaron Ward. Always a joy to the owner, absolutely distinct. Color coppery-orange in the open bud, golden-orange when partly developed, pinkish-fawn of lovely shade when fully open. Everybody falls in love with it who sees it. 50 cts. each.

Madam Constant Soupert. Dark golden yellow, strongly tinted peach-pink, large, full and perfectly formed. $30 \mathrm{cts}$.

Richmond. Pure rich scarlet, very free and continuous flowering.

Radiance. A brilliant rosy-carmine, displaying beautiful rich opaline-pink tints in the open flower. Fine form, large size and constant bloomer. 50 cts. each.

Any five of those priced at $50 \mathrm{cts}$. for $\$ 2$. Any five "priced at 40 cts. for $\$ 1.50$.

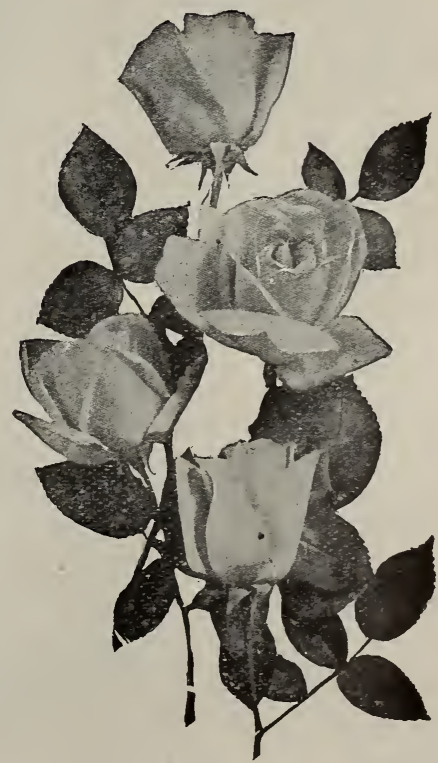

KILLARNEY 


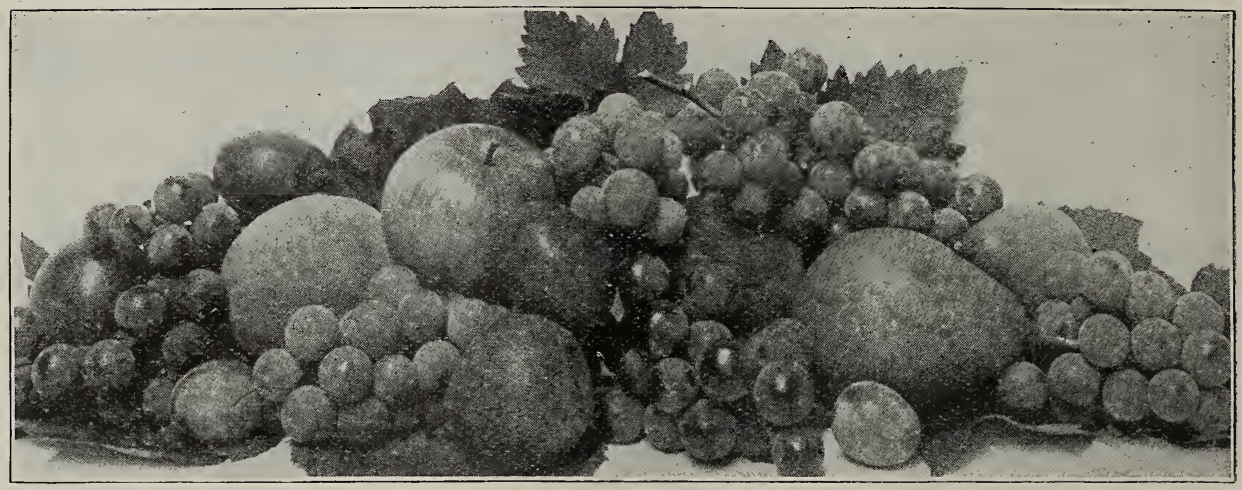

\section{FRUIT DEPARTMENT}

\section{APPLES}

First-class, 5 to $7 \mathrm{ft}$., 35 cts. each, $\$ 3$ per doz.

Summer Varieties. Yellow Transparent, Early Harvest, Red Astrachan, Sweet Bough.

Autumn Varieties. Fall Pippin, Gravenstein, Maiden's Blush, Twenty Ounce, Pippin, Fameuse, Fallawater.

Winter Varieties. Baldwin, Ben Davis, Golden and Roxbury Russet, King, Mann, Spy, R. I. Greening, etc.

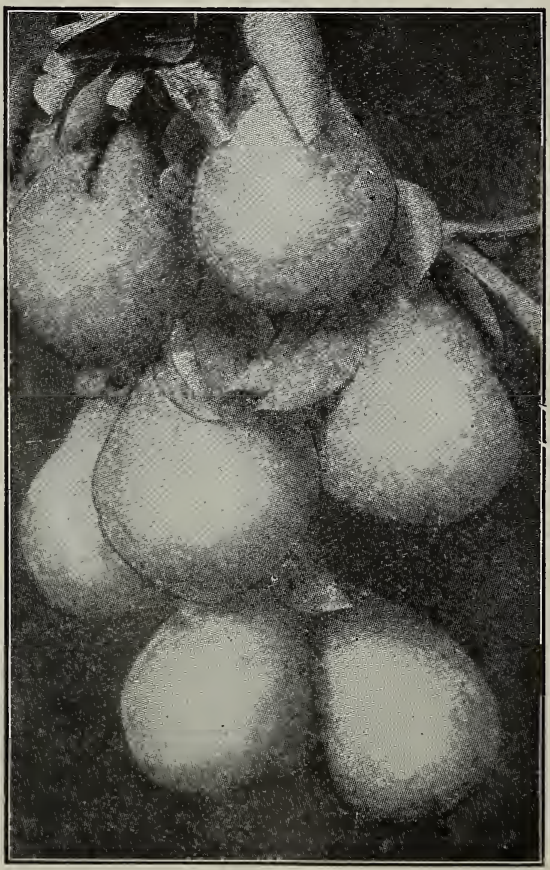

LAWRENCE PEARS

\section{CRAB APPLES}

First-class, 5 to $7 \mathrm{ft}$., $40 \mathrm{cts}$. each, $\$ 3.50$ per doz.

Hyslop, Martha, Large Red Siberian, Yellow Siberian, Transcendent, Orange, etc.

\section{PEARS}

First-class, 5 to $7 \mathrm{ft}$., $50 \mathrm{cts}$. each, $\$ 4$ per doz. $\$ 35$ per 100

Summer Varieties. Clapp's Favorite, Osband's Summer, Wilder.

Autumn Varieties. Bartlett, Anjou, Seckel, Sheldon, Duchess.

Winter Varieties. Kieffer, Lawrence.

\section{PLUMS}

European Varieties. German Prune, Imperial Gage, Damson, Yellow Egg. First-class, 4 to $5 \mathrm{ft}$., 40 cts. each, $\$ 4$ per doz.

Japan Varieties. Burbank, Abundance, Wickson, etc. 40 cts. each, $\$ 4$ per doz.

\section{CHERRIES}

First-class, 5 to $7 \mathrm{ft}$., $50 \mathrm{cts}$. each, $\$ 5$ per doz.

Sour Varieties. Early Richmond, May Duke, Louis Phillippi, Montmorency.

Sweet Varieties. Black Tartarian, Coe's Transparent, Gov. Wood, Napoleon Bigarreau, Rockport Bigarreau, Windsor, Yellow Spanish.

\section{PEACHES}

Leading Sorts. First-class, 35 cts. each, $\$ 2.50$ per doz. Special prices on large quantities.

\section{QUINCES}

Orange and Champion. 40 cts. each, $\$ 4$ per doz. Meech's. 50 cts. each, $\$ 5$ per doz. 


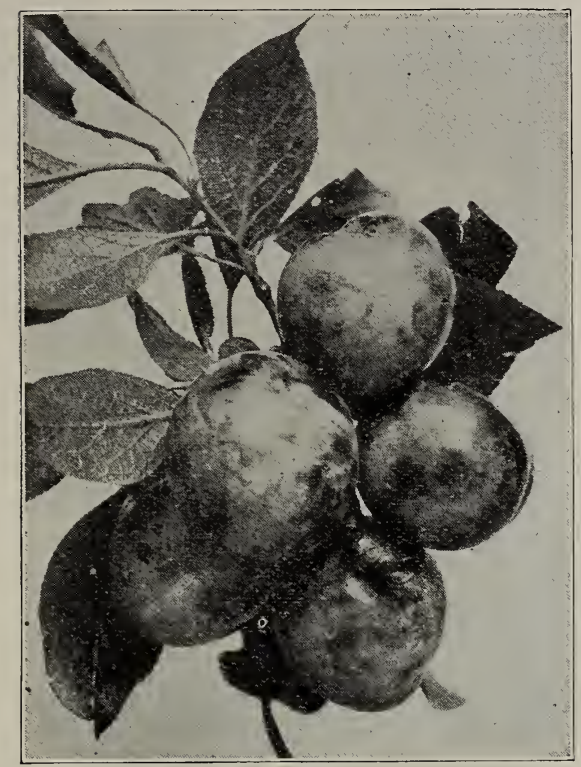

Burbank Plum

\section{SMALL FRUITS}

Blackberries. Early Harvest, Wilson's Early, Erie, Kittatinny, etc. 75 cts. per doz., $\$ 4$ per 100 .

Raspberries, Red. 75 cts. per doz., $\$ 2.00$ per 100. Black. 75 cts. per doz., $\$ 2.50$ per 100 .

Gooesberries. Downing, Smith's Improved, Red Jacket, etc., 2 years, $\$ 2$ per doz.

Currants. Cherry, White Grape, Black Naples and Fay's Prolific, 2 years. $\$ 1.50$ per doz.

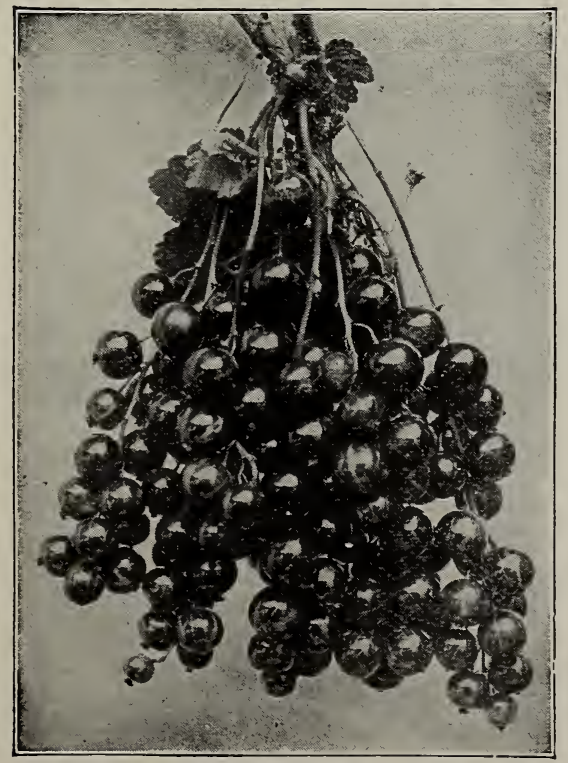

FAy's Prolific

\section{ST. REGIS EVERBEARING RASPBERRY}

St. Regis Everbearing Raspberry. The most wonderful Raspberry ever introduced.

There are a number of so-called everbearing Raspberries, but this is the first real triumph as it is positively everbearing, producing continuous crops of luscious red berries till hard frosts, often into November.

We are pleased to be able to offer this grand fruit at the reduced price of $\$ 1.00$ per doz., $\$ 3.50$ per 100 plants.

For large quantities for commercial planting write for prices.

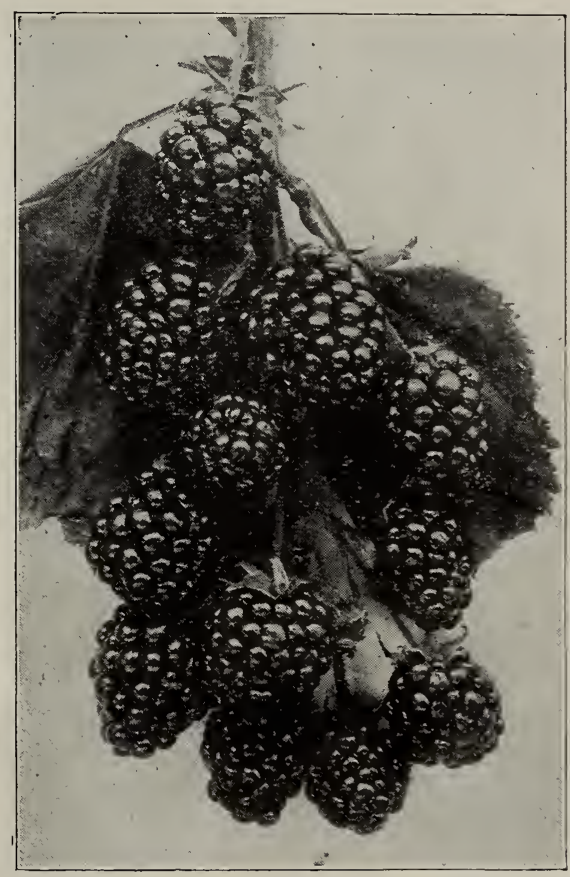

St. Regis Everbearing Raspberry

\section{GRAPE VINES}

2 and 3-year-old plants, first-class. B., black; W., white; R., Red

Agawam, R.; Moore's Early, B. 25 cts. each, $\$ 2.50$ per doz.

Concord, B. 25 cts. each, $\$ 2.50$ per doz.

Delaware, R.; Pocklington, W. 25 cts. each, $\$ 2.50$ per doz.

Martha, Empire State and Niagara, W. 35 cts. each, $\$ 3$ per doz.

Moyer, R. New. 25 cts. each, $\$ 2.50$ per doz.

Moore's Diamond. W. New. 30 cts. each, $\$ 2.25$ per doz.

Salem, R. 25 cts. each, $\$ 2.50$ per doz.

Campbell's Early, B. New. Pulp sweet; seeds part readily. 2 year, 35 cts. each. 


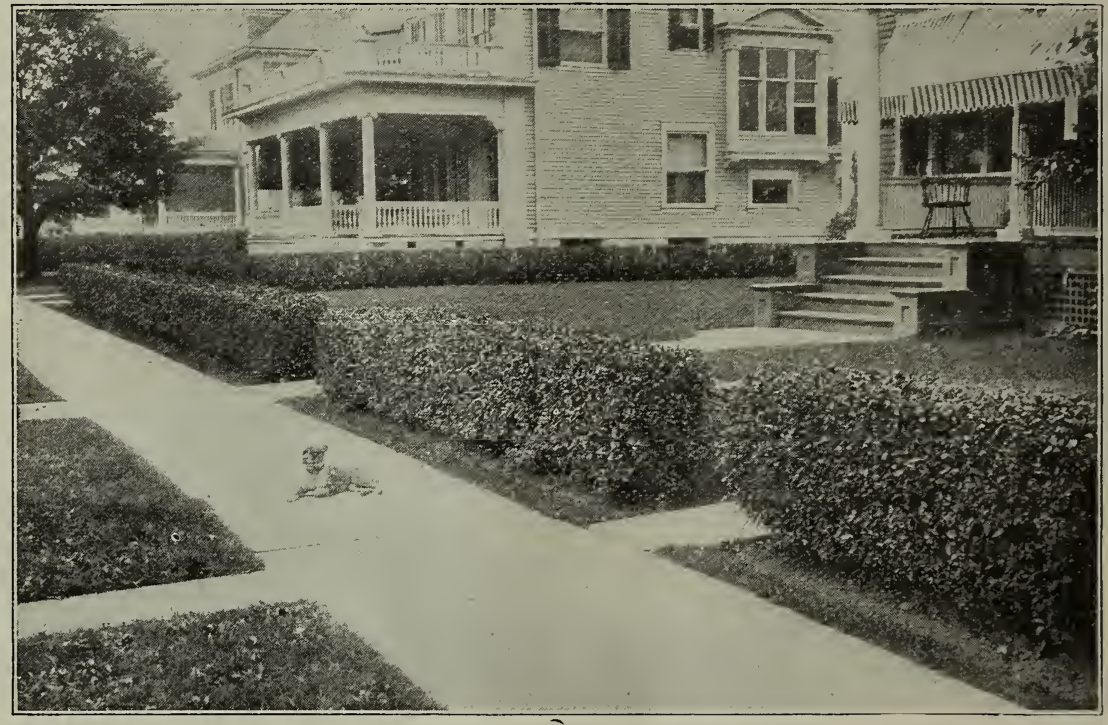

\section{LANDSCAPE DEPAR TMENT}

After some years of experience in this line we are prepared to execute any contemplated landscape work upon the most favorable terms.

Upon application, a competent man will visit and inspect either old or new places with a view to planting or remodeling.

Plans and estimates cheerfully furnished-upon visit or receipt of specification-for any desired work of this kind, for which no charge will be made, provided all the stock is supplied by us.

It is our custom to guarantee our planting for one year, and we replace free of charge any trees or plants failing to grow within that time, unless damaged by carelesness after work is finished. This gives the customer full protection, and insures the planting of strong, healthy stock.

Many country places may be wonderfully improved, at a very moderate expense by the efforts of an intelligent person, experienced in this line, by having stock, planning and planting come under one contract.

We respectfully solicit your correspondence.

We refer you to-Dr. Albert Shaw, of Hastings-on-Hudson; Mr. Alexander Christie, President Park Commission, Bayonne, N. J.; Franciscan Sisters, Peekskill, N. Y.; St. Mary's School, Peekskill, N. Y.; Mr. G. P. Hutchins, Larchmont, N. Y. 


\section{TESTIMONIAIS}

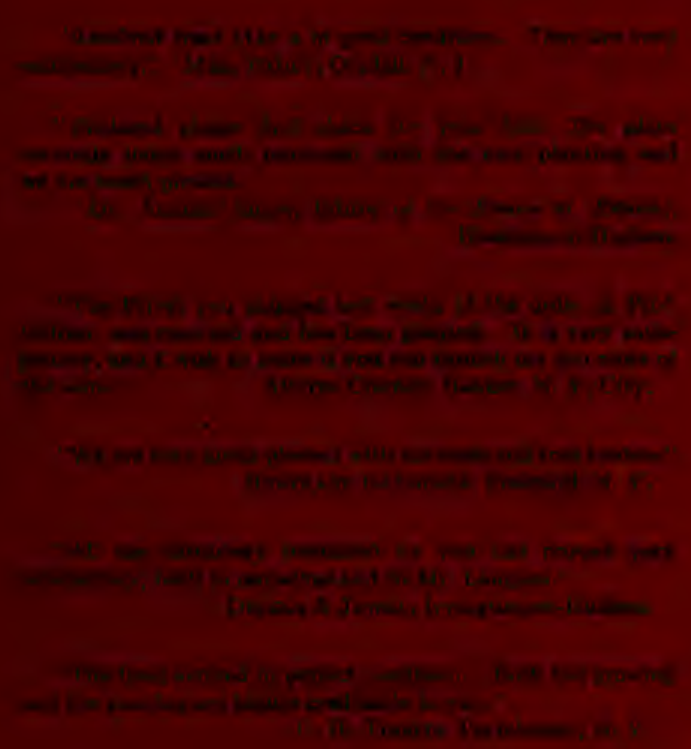

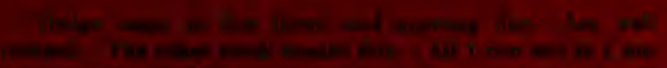

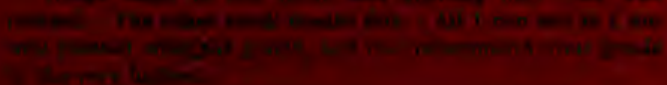

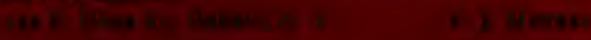

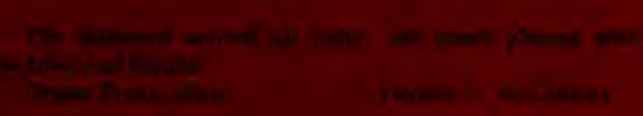

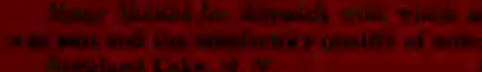

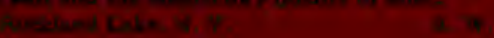
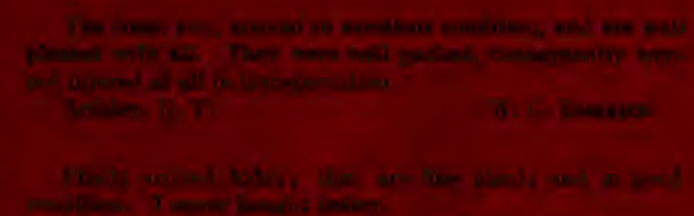

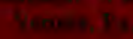

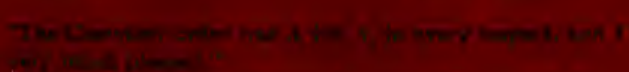

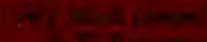

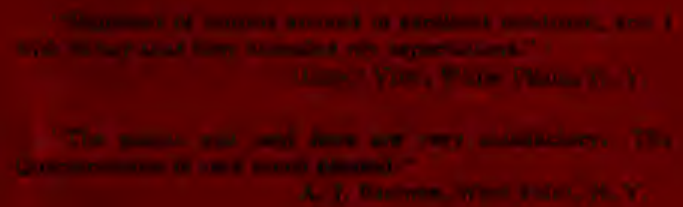

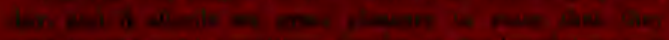

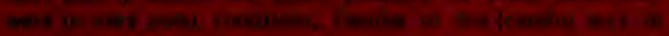

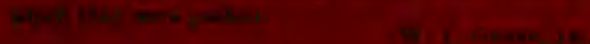

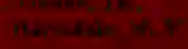

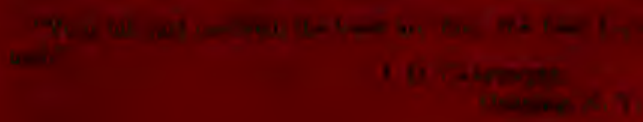


Monrrose Numeriet

MONTROSE

Wratiestes County Now Yort

-6 m the

$-$ 